\title{
فعالية برناهج علاجي باستخدام الألعاب التعاونية في تنمية هستوى الانتباه لطلاب الصف الأول المتوسط ذوي صعوبات التعلم في دولة الكويت
}

\author{
إعـداد \\ أ.د.// عادل عبد الله محمد التحد \\ أستاذ التربيت الخاصت \\ وعميد كليت علوه الإعاقت والتأهيل \\ جامعت الزقازيق الأقاقيق \\ الباحثت / شيخت يوسف علي الأنصاري \\ باحثت دكتوراه
}




$$
\text { ملخص البحث }
$$

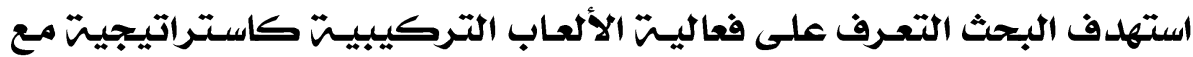

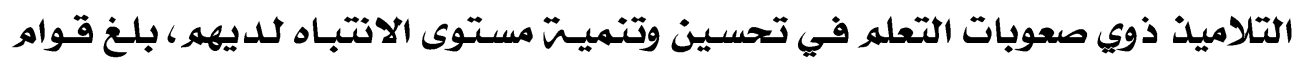

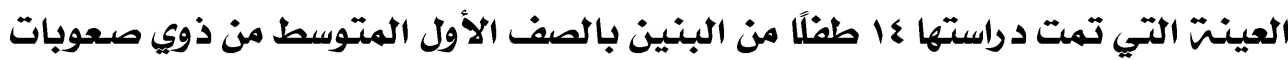

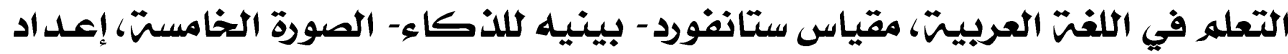

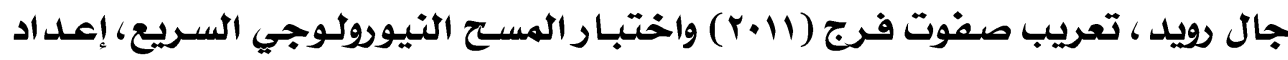

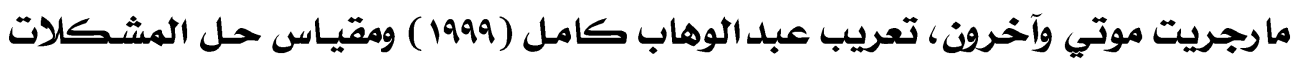

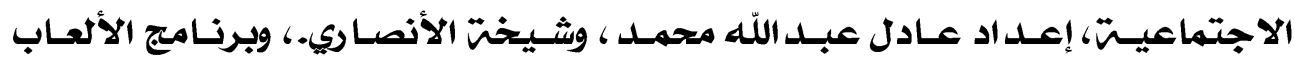

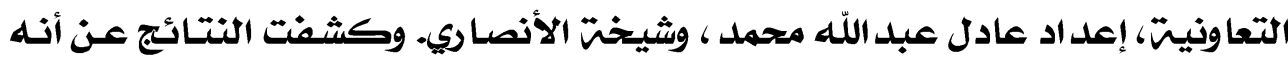

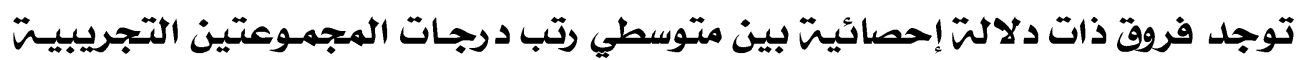

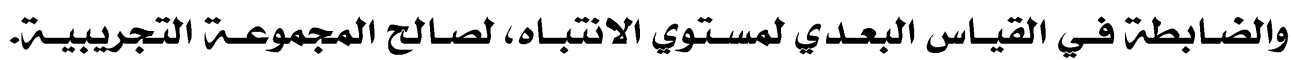

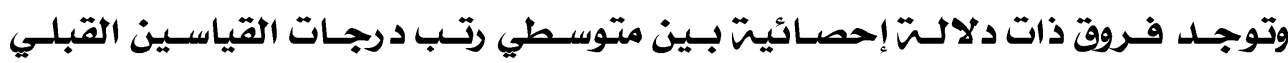

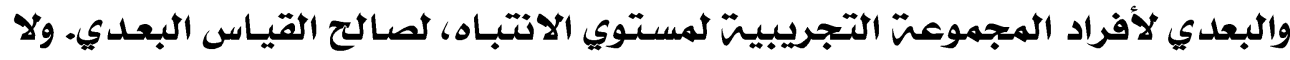

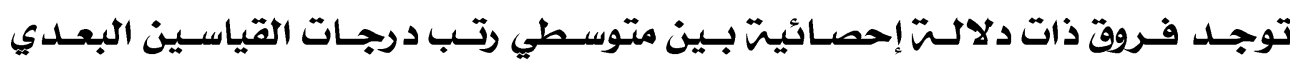

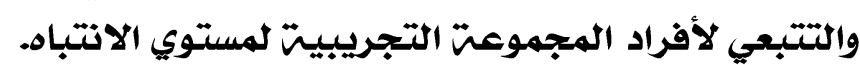

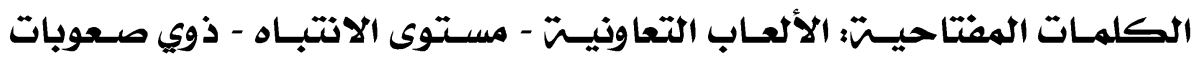


The effectiveness of a therapeutic program using cooperative games in developing the level of attention for first-grade intermediate students with learning difficulties

\section{In the State of Kuwait}

The research aimed to identify the effectiveness of synthetic games as a strategy with students with learning difficulties in improving and developing their level of attention. The sample studied was 14 boys in the first intermediate grade with learning difficulties in the Arabic language, the Stanford-Binet Intelligence Scale - the fifth picture, Prepared by Gal Royed, Arabization of Safwat Faraj (2011) and the Neurological Rapid Survey Test, prepared by Margaret Moti and others, Arabization of Abdel Wahab Kamel (1999) and the Social Problem Solving Scale, prepared by Adel Abdullah Mohammed and Sheikha AlAnsari, and the cooperative games program, prepared by Adel Abdullah Mohammed and Sheikha Ansari. The results revealed that there are statistically significant differences between the mean scores of the two experimental groups

and the control group in the post-measurement of the level of attention, in favor of the experimental group. There are statistically significant differences between the mean scores of the two measurements, the pre and post measurements, for the members of the experimental group for the level of attention, in favor of the post measurement. There are no statistically significant differences between the mean scores of the post and follow-up measurements of the experimental group members for the level of attention.

Keywords: cooperative games - attention level - people with learning disabilities. 
مقدمت:

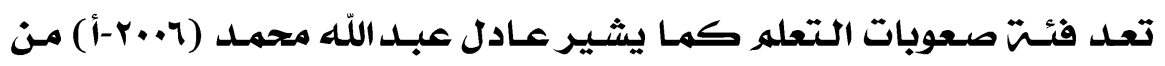

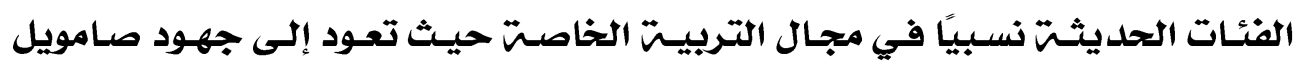

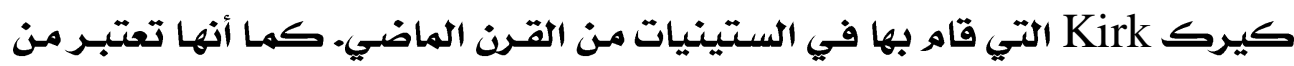

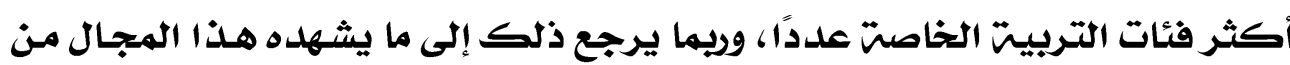

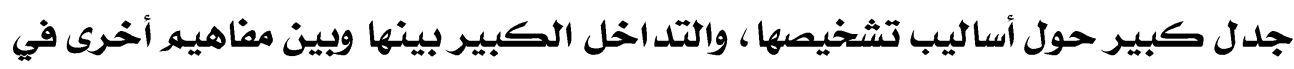

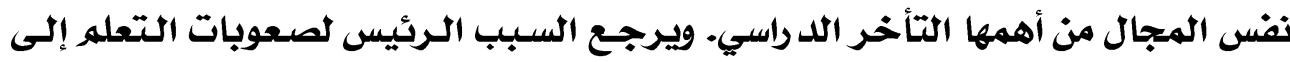

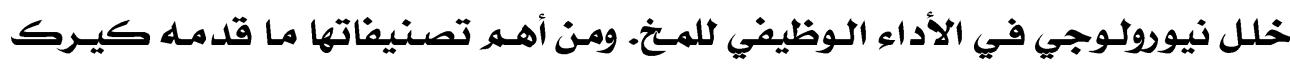

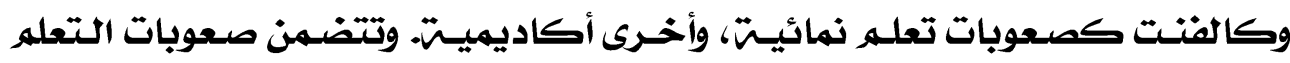

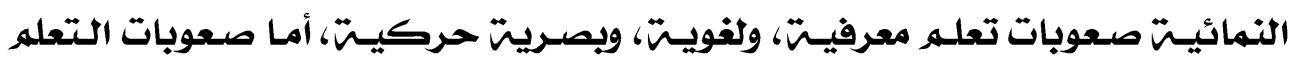

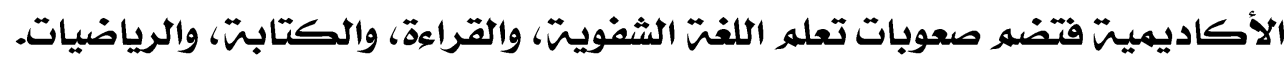

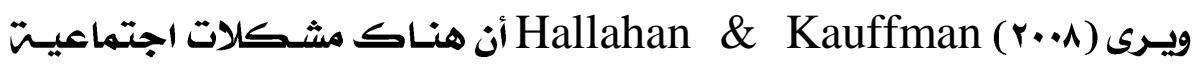

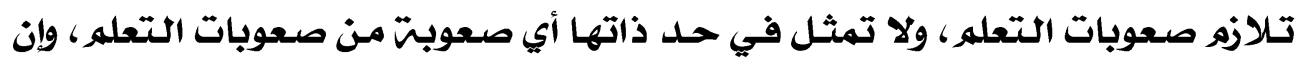

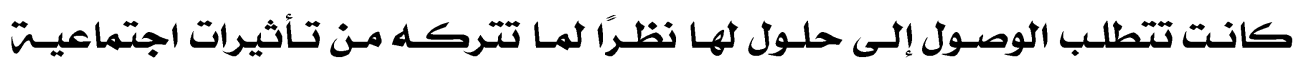

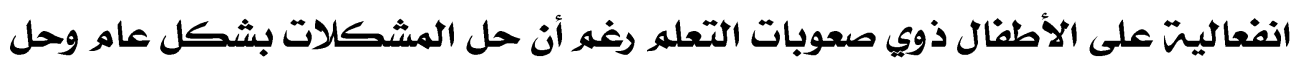

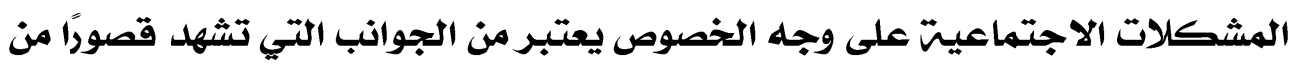
جانب الأطفال ذوي صعوبات التعله.

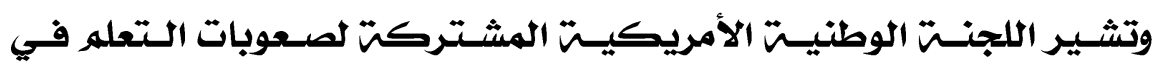

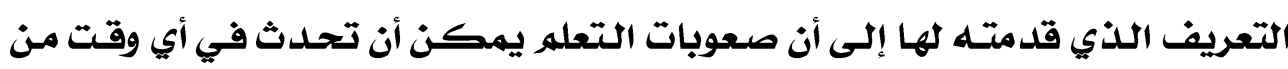

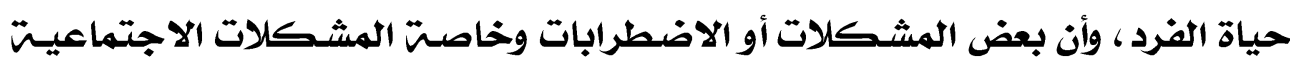

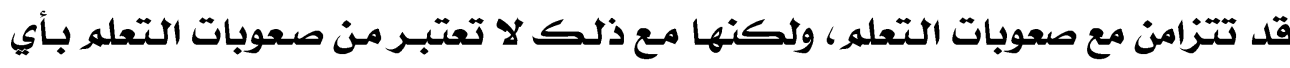

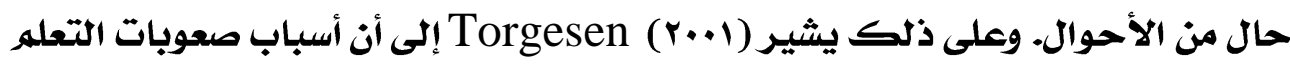

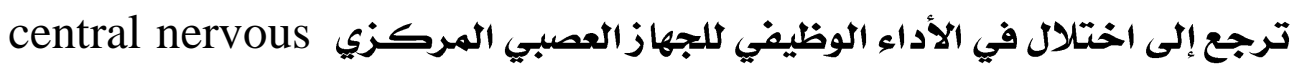
وهو مystem dysfunction

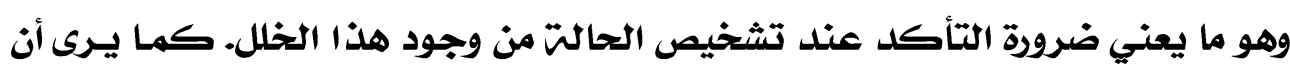

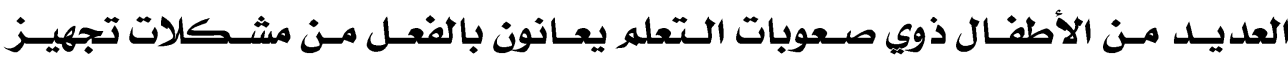

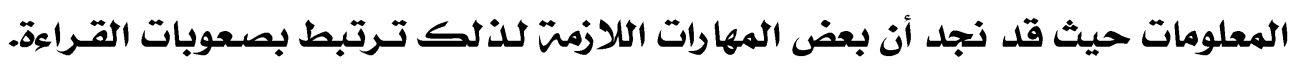

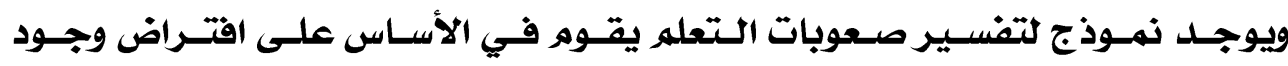
مشكات في تجهيز المعلومات لدى هؤلاء الأطفال.

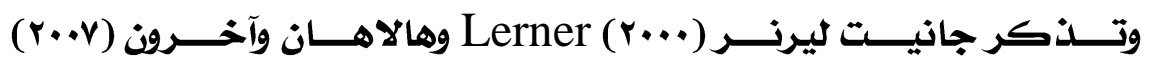
Hallahan et al

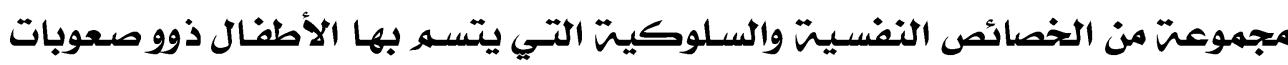
التعلهر من أهمها ما من يلي: 
التباين بين الشخصي في مستوى الصعوبات.

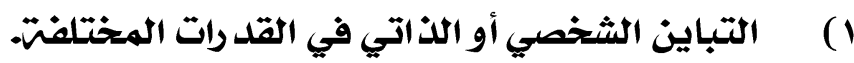

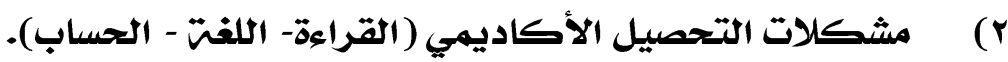

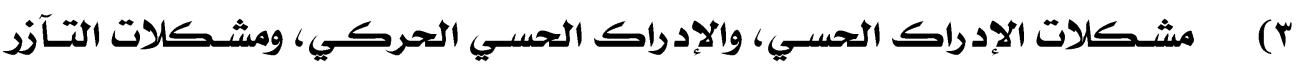

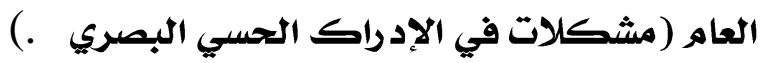

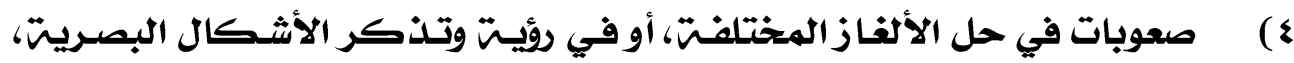

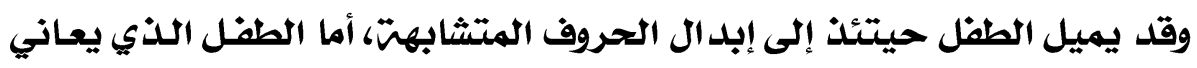

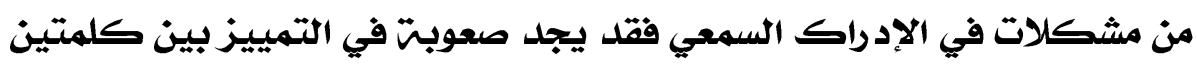

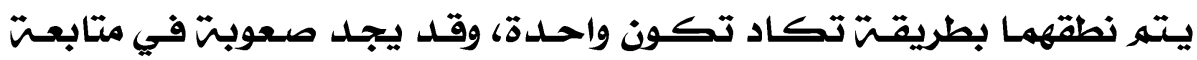

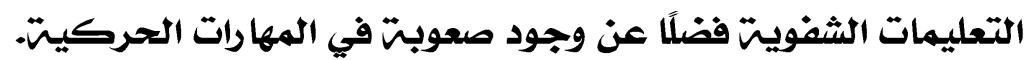

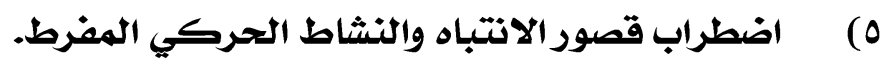

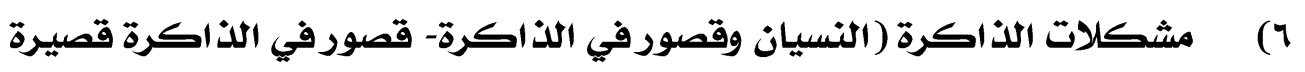

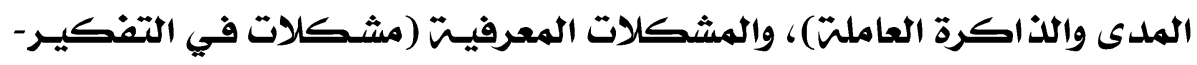

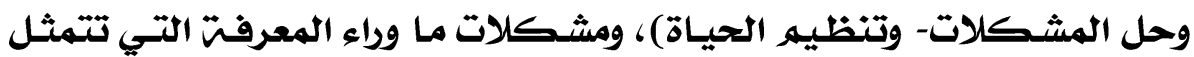

أ- القدرة على إدراك المتطلبات اللازمتّ لأداء مهمت معينتة.

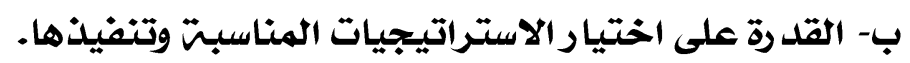

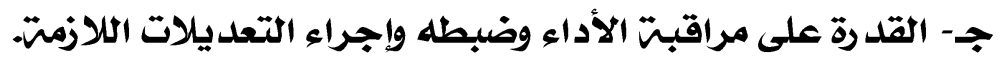

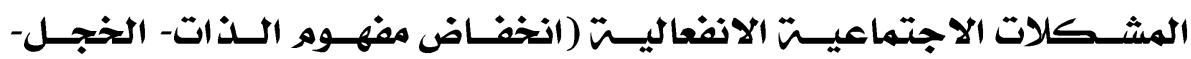

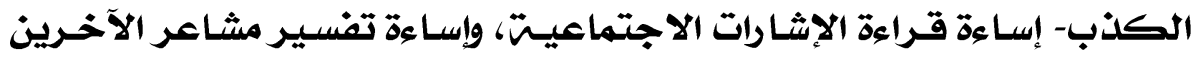

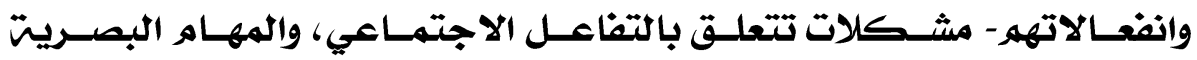

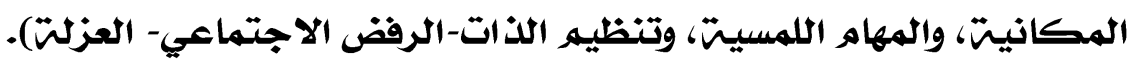

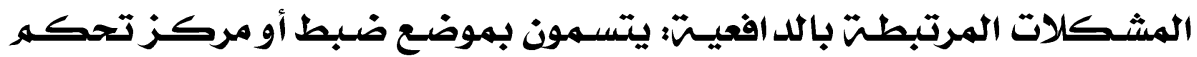

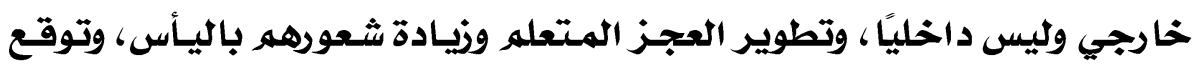

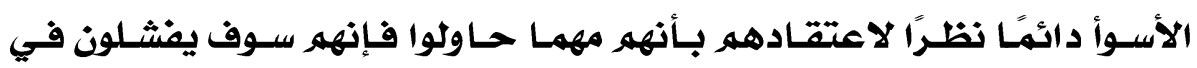

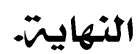

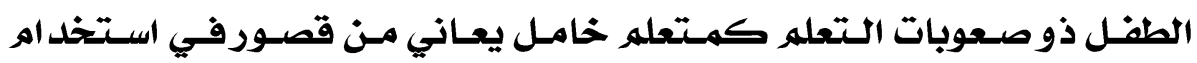

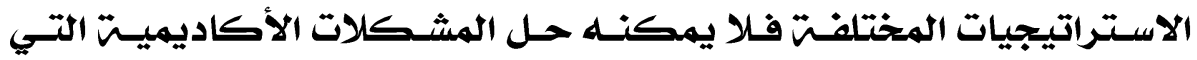

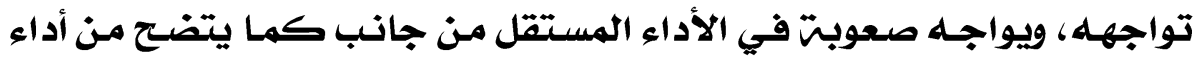

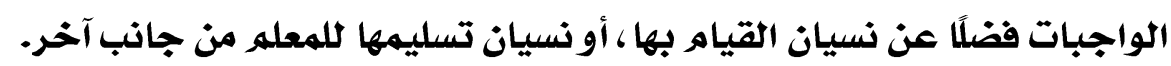

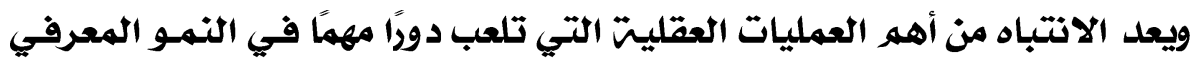

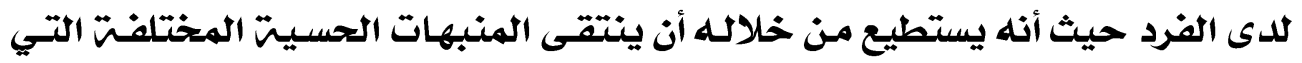




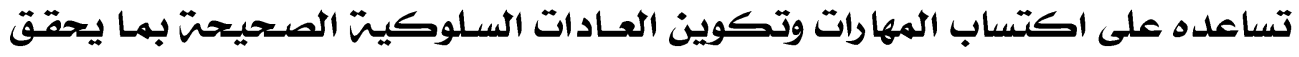

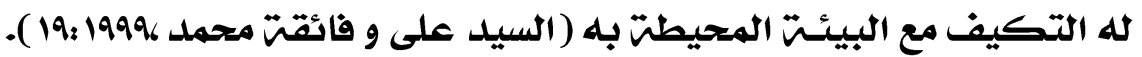

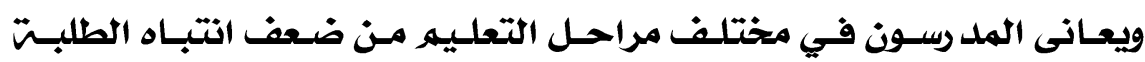

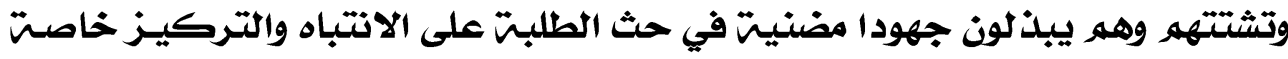
عند شرح موضوع جديد ، ويلجاً بعضهه إلى معاقبـت الطالب للفت انتباهـه باستمرار

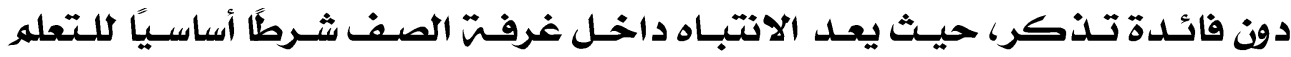

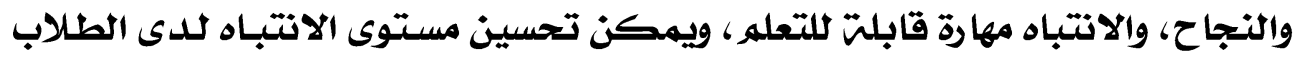

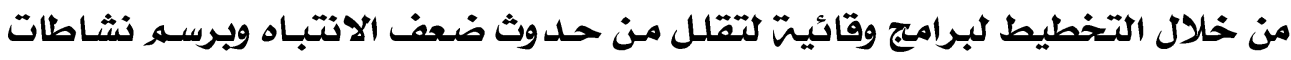

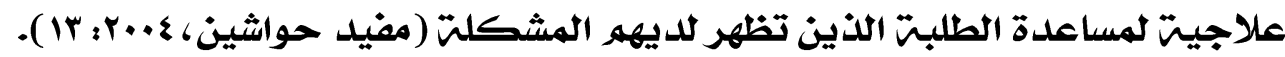
ويعد الانتباه عمليت وظيفيت في الحيـاة العقليـتة، تقـوه بتوجيـه شعور الفـرد

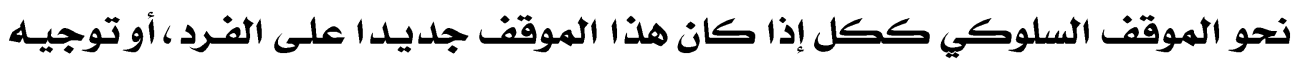

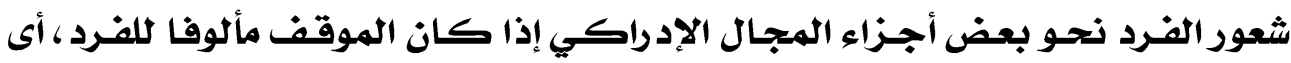

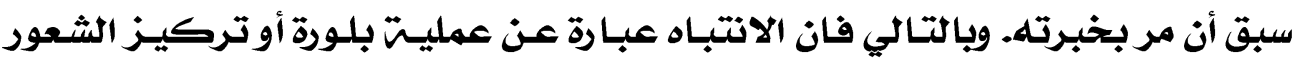

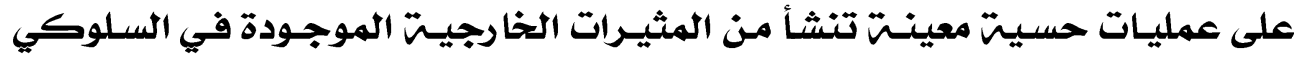

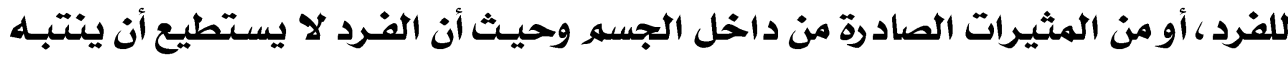

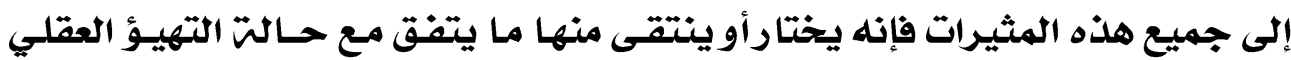

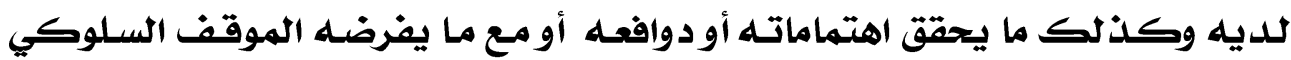

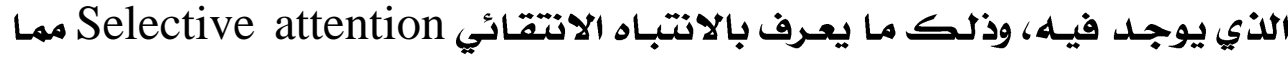

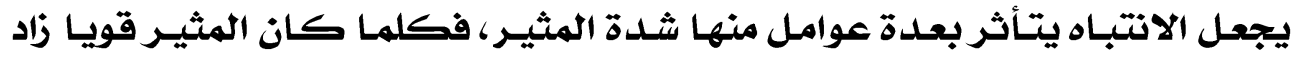

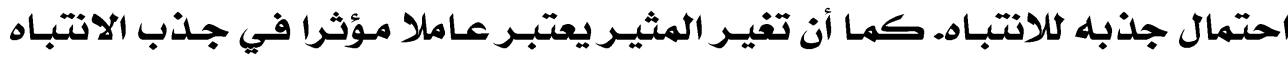

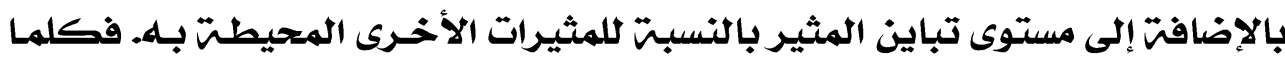

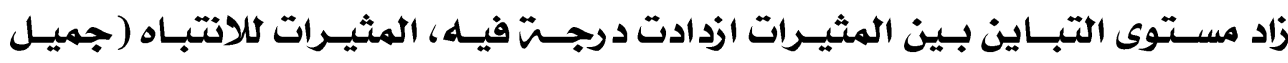

$$
\text { مشكلت البحث: }
$$

يعد قصور الانتباه من أبرزمشكاتهلات الأطفال ذوى صعوبات التعله وخصوصًا

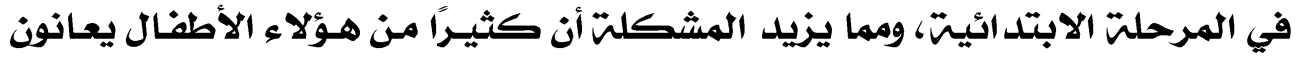

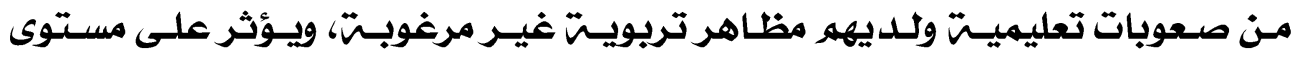

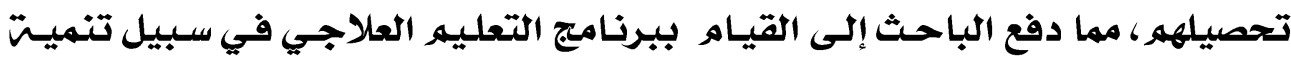

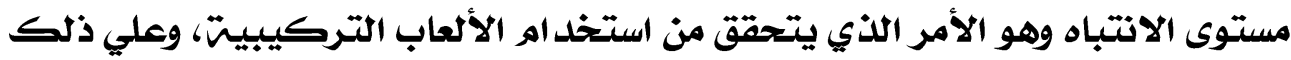

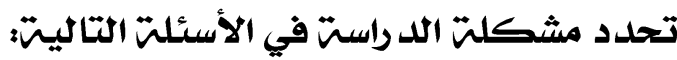
وعلي ذلك تتمثل مشكلت البحث في الأسئلت التاليتي: 
هل توجد فروق بين متوسطي رتب درجات المجمـوعتين التجريبيـت والضـابطت

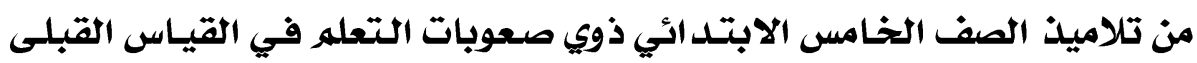

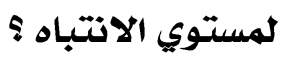
هل توجد فروق بين متوسطي رتب درجات الهجموعت التجريبيتت في القياسين

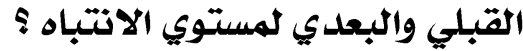
هل توجد فروق بين متوسطي رتب درجات المجموعت التجريبيت في القياسين

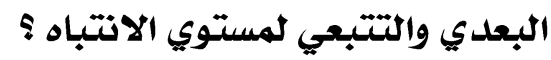
تهدف الدراست الحاليت إلي:

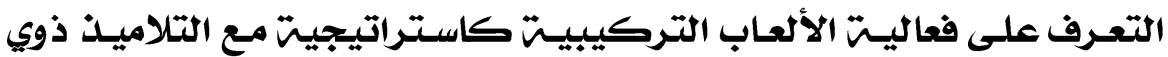

صعوبات التعله في تحسين وتتميت مستوى الانتباه لديهر.

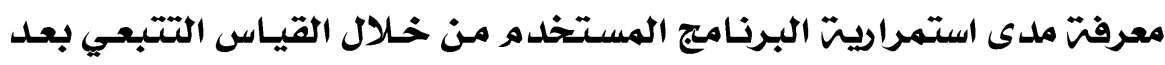

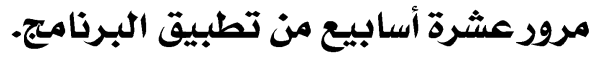

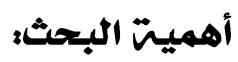

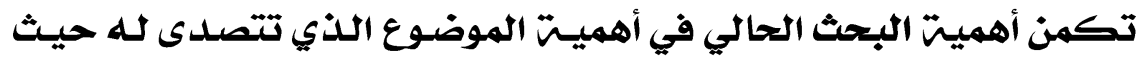

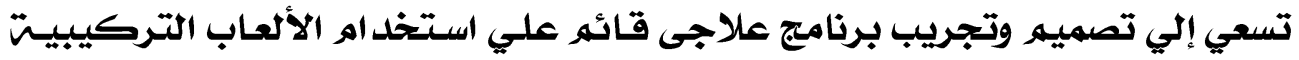

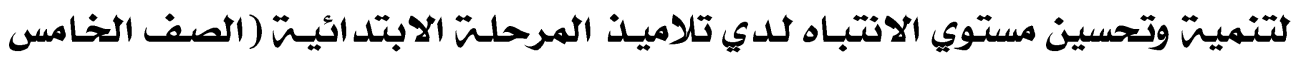

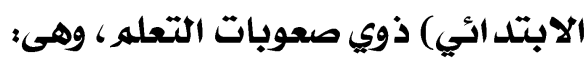

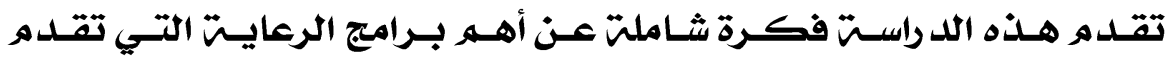
كلأطفال ذوى صعوبات التعله.

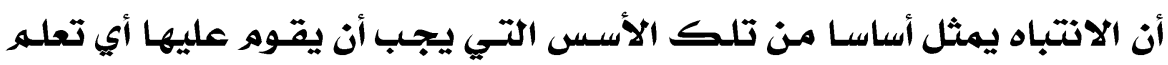
لاحق يتهر تقلديمه لمثل هؤلاء الأطفال.

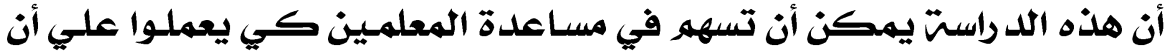

$$
\text { يقدموا لهه ذلك انده التعليه. }
$$

$$
\text { مصطلحات البحث: }
$$

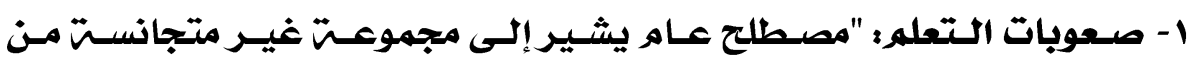

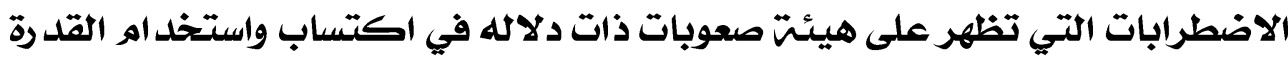

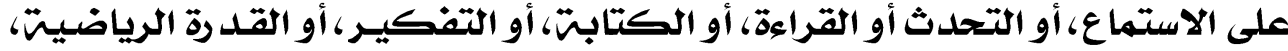

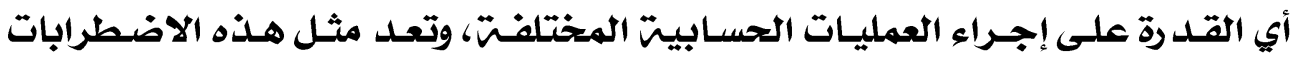

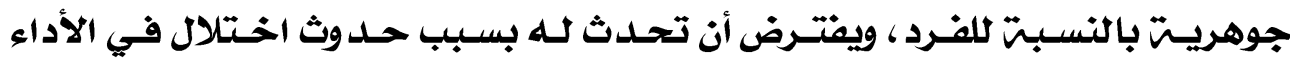

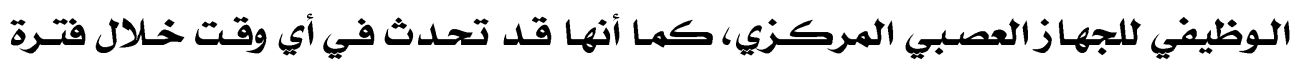


حياته، هـذا وقد تحدث مشكاتلات في السـلوكيات الد التّ على التنظيهر الذاتي،

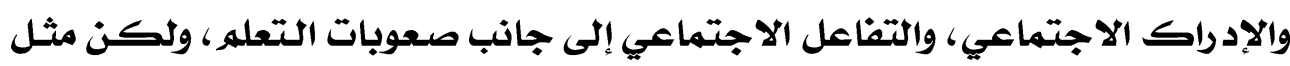

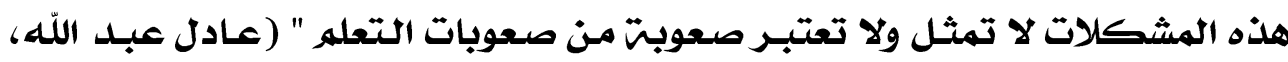

(Yq, T. P.)

r- قصور الانتباهء "هو حالت تعنى عده قدل رة الطفل على التركيـز والانتبـاه

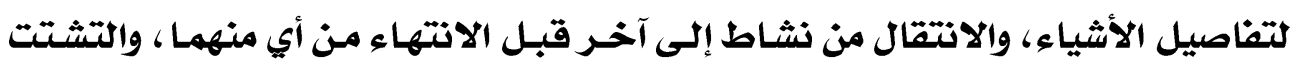

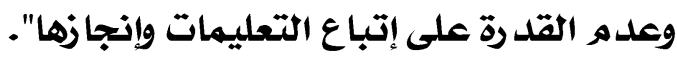

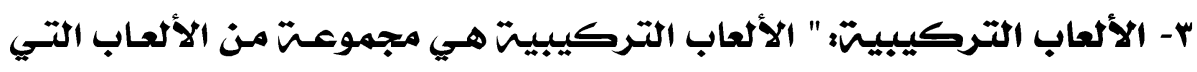

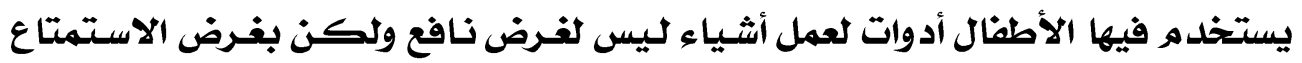

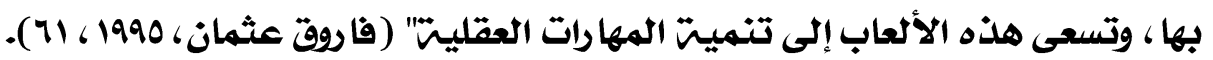

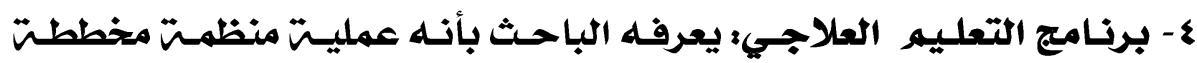

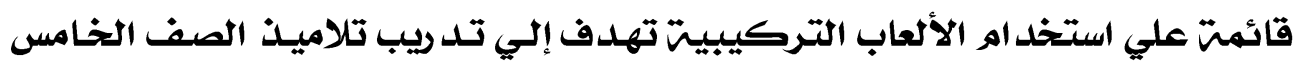

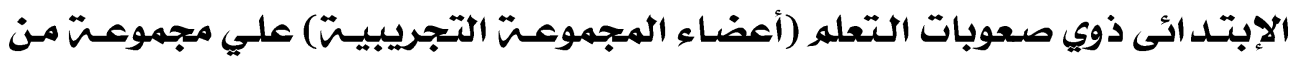

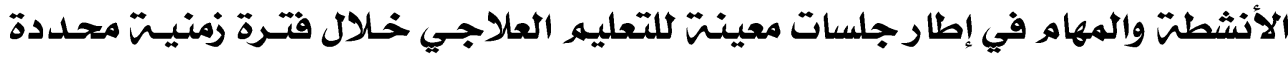
بغرض تنميت مستوى الانتباه لد يهه.

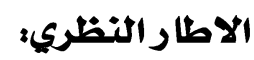

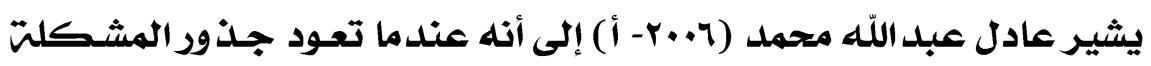

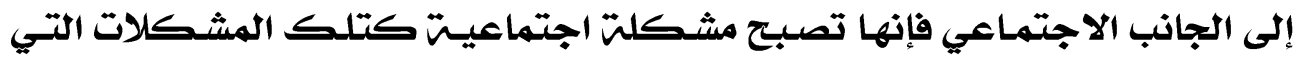

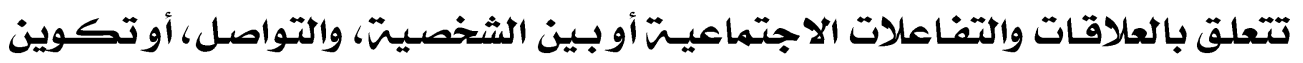

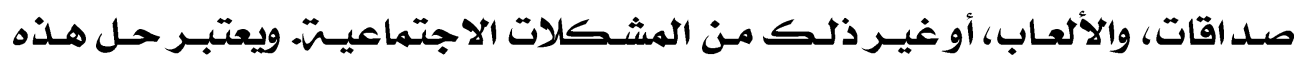

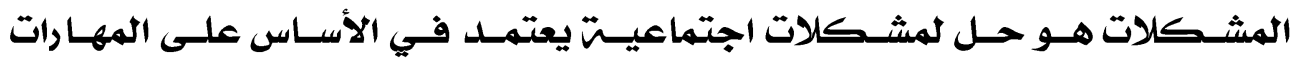

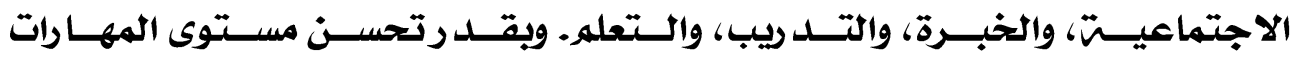

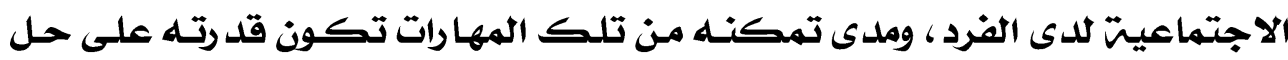

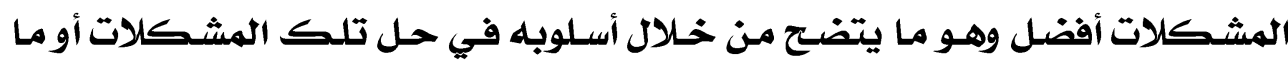
يعرف بسلوك حل المشكات الاجتماعيتت من جانبه.

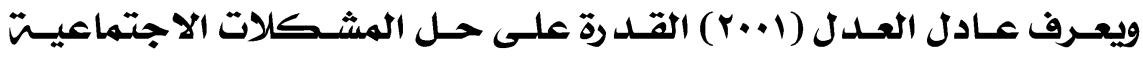
Social problem solving ability

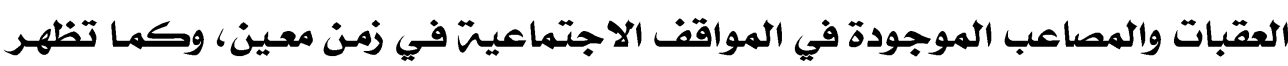

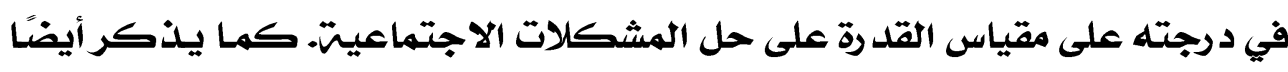

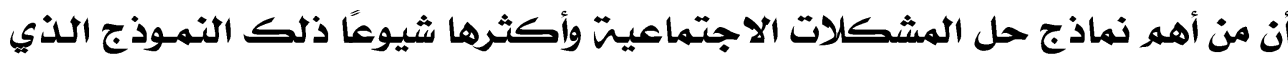

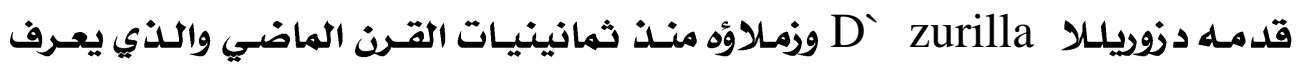


بالنموذج الوصفي لحل المشكات الاجتماعيت والذي تشمل عمليت حل المشكات فيلات

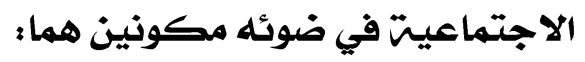

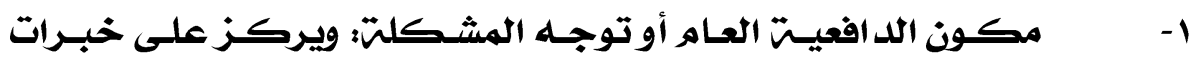

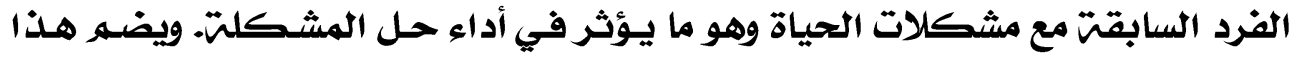

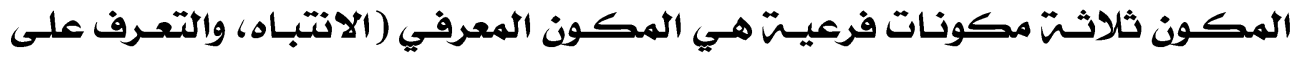

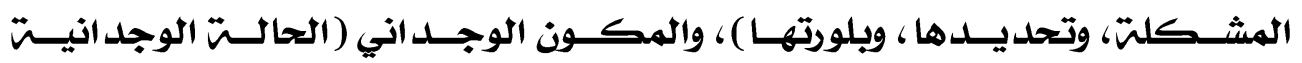

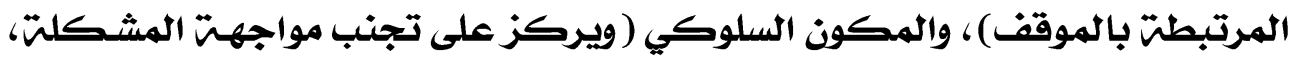

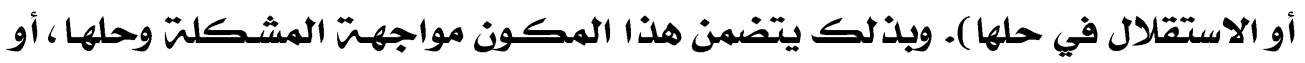
تجنبها والاعتماد على الآخرين في حلها.

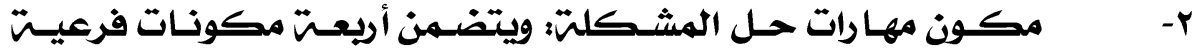

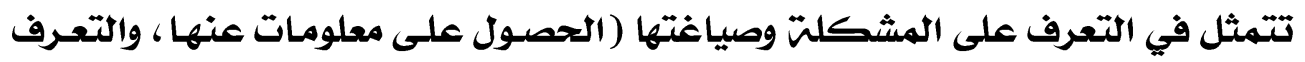

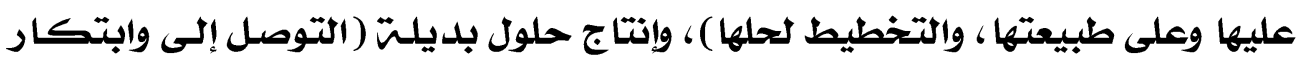

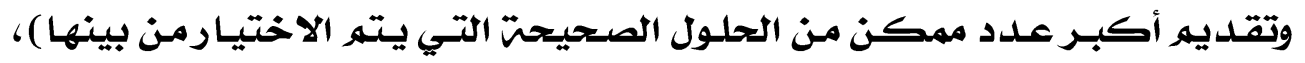

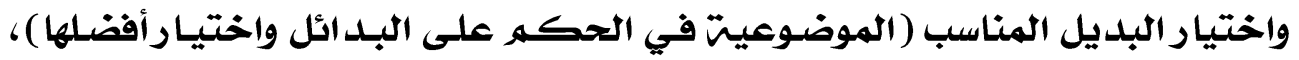

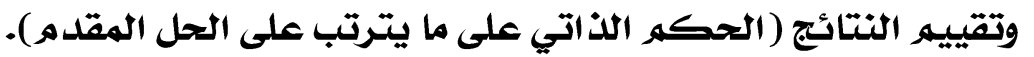

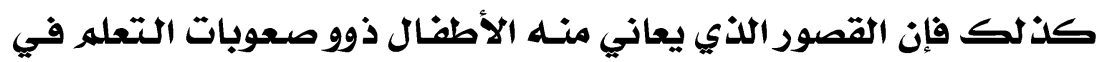

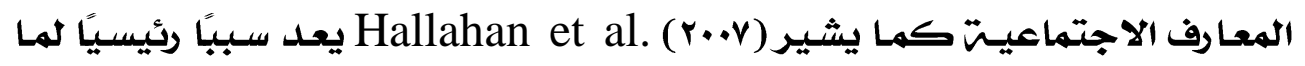

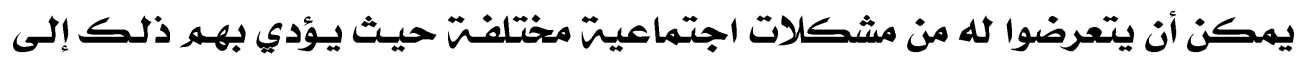

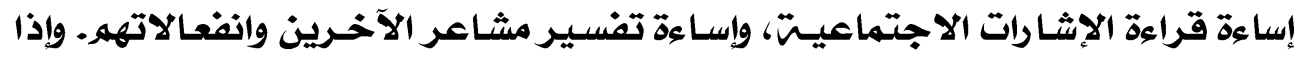

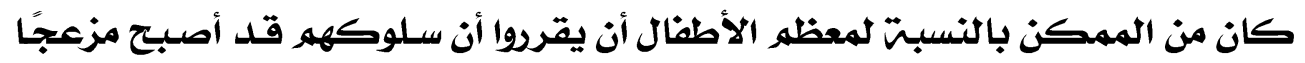

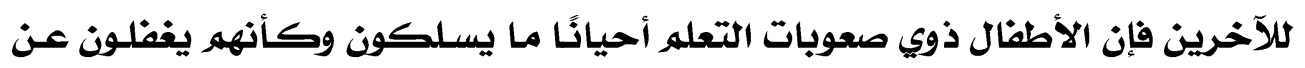

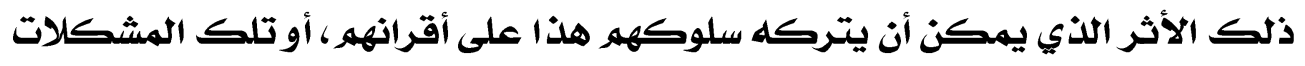

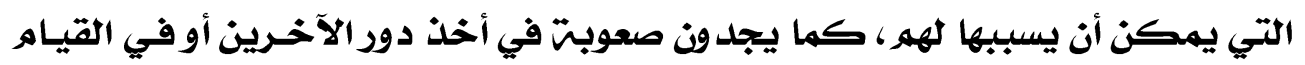
بوضع أنفسهر مكان هؤلاء الآخرين.

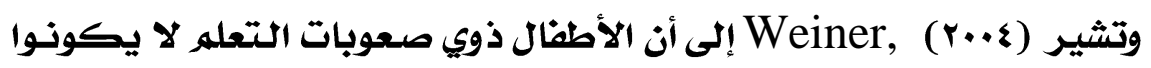

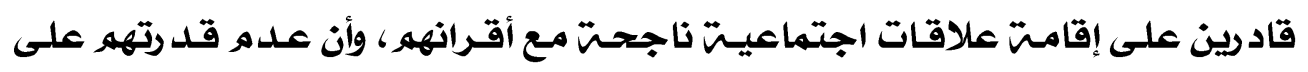

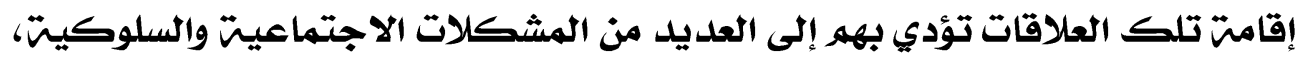

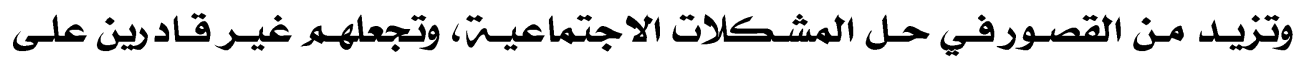

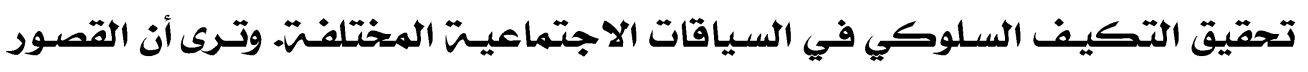

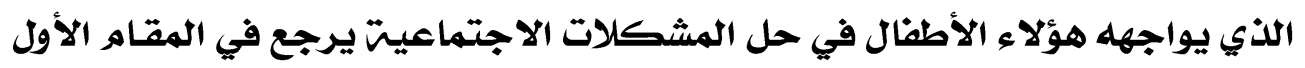

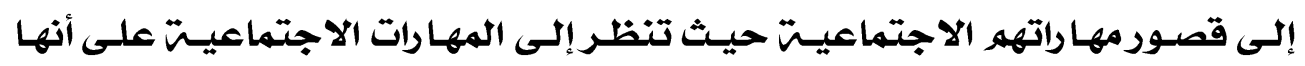

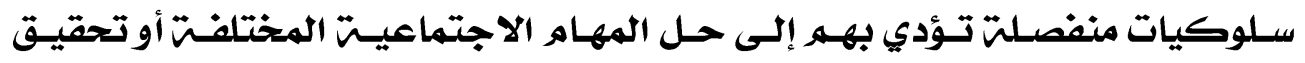

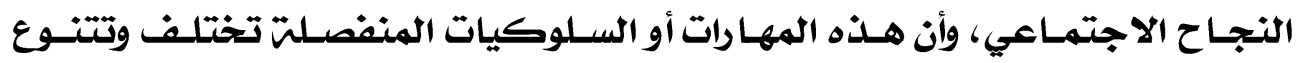




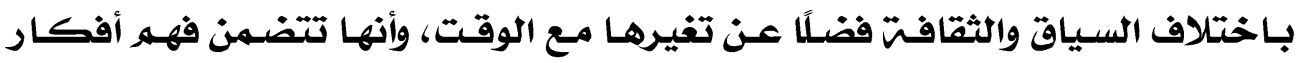

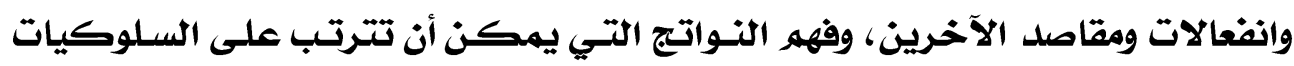

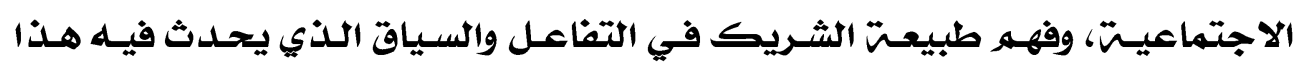

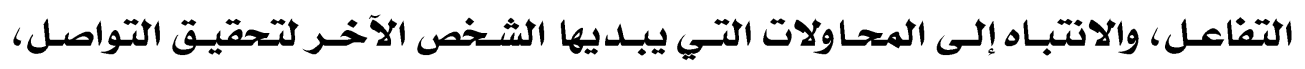

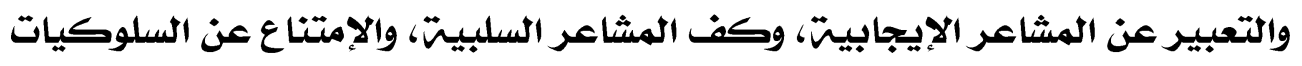

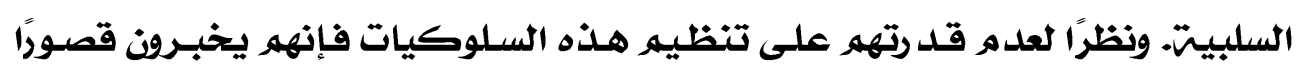

واضحًا فيها لا يمكنهه من حل المشكاتلات الاجتماعيت التي تواجهرهم.

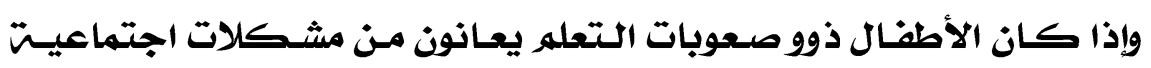

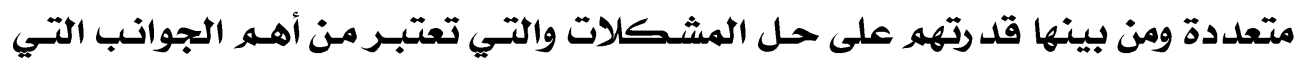

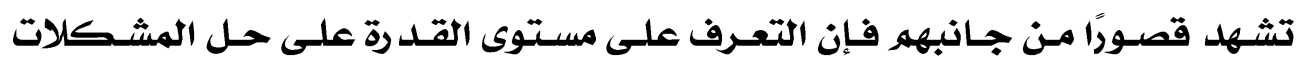

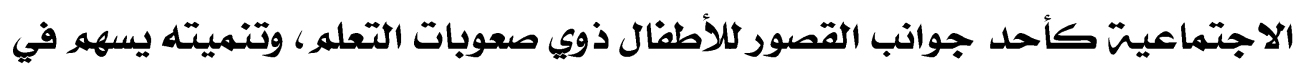

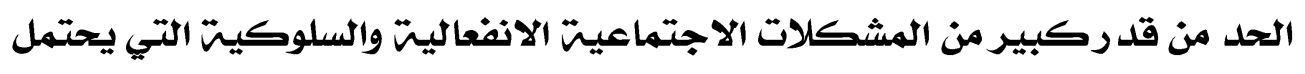

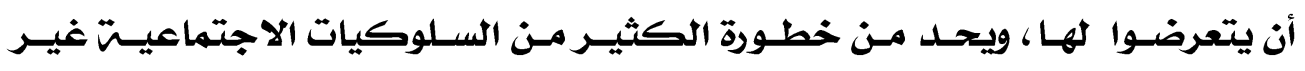

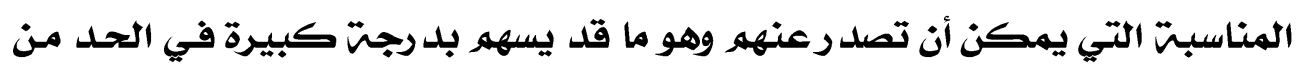

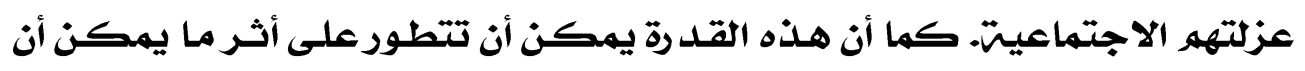

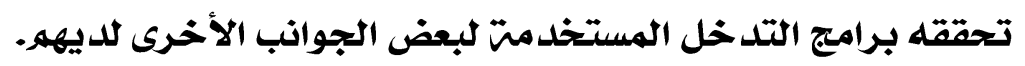

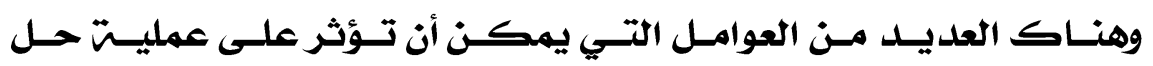

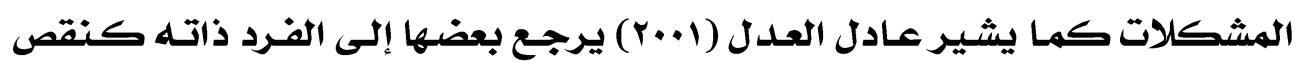

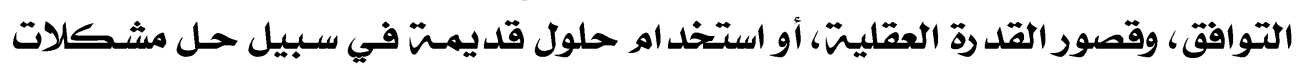

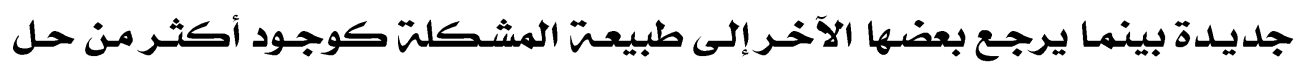

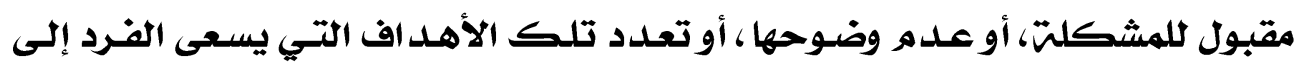

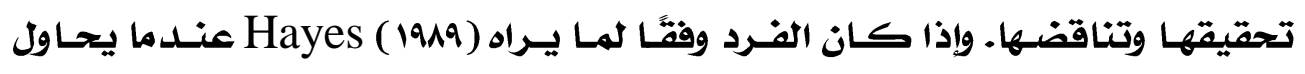

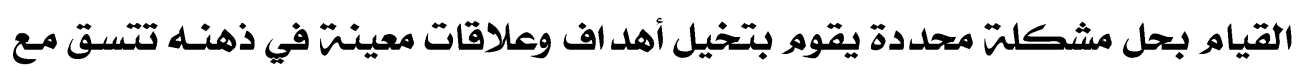

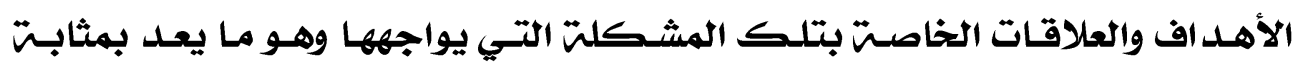

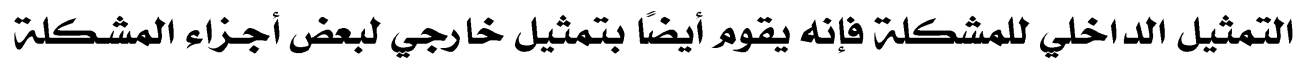

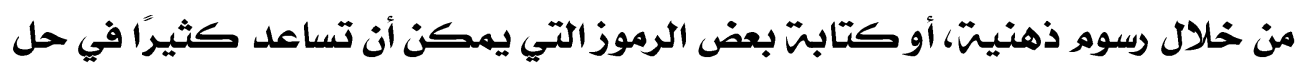

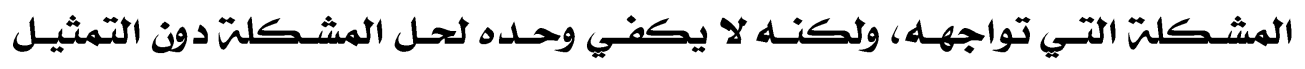

$$
\text { الد اخلي لها. }
$$

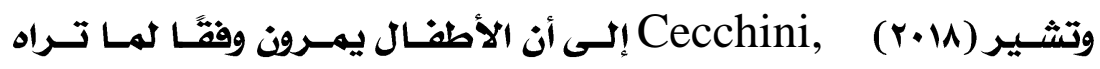

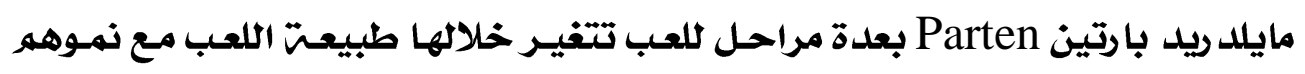

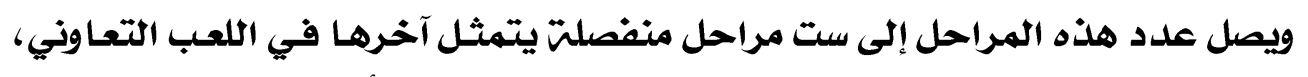

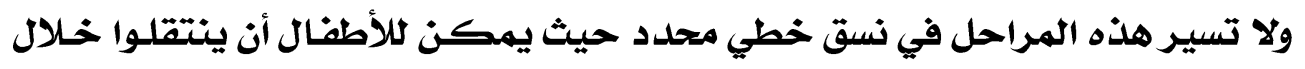




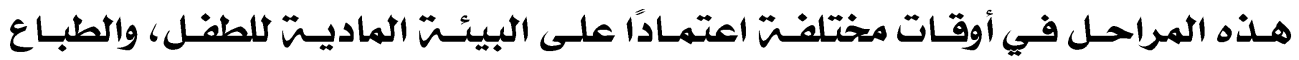

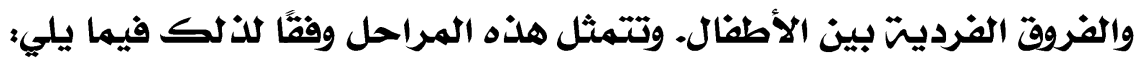

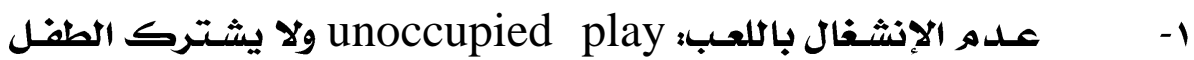

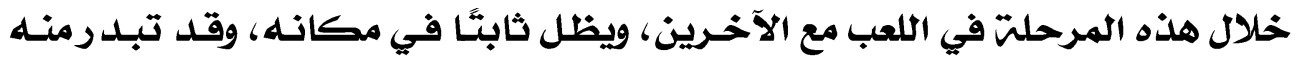

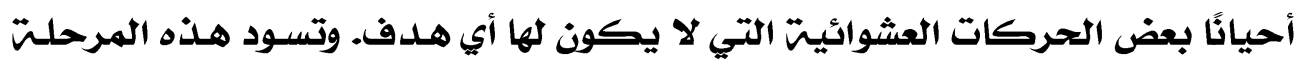
خلال أول عامين من عمر الطفل.

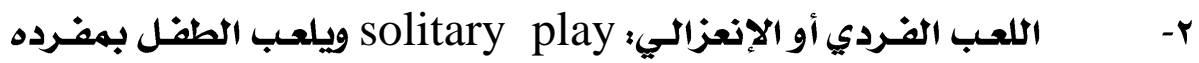

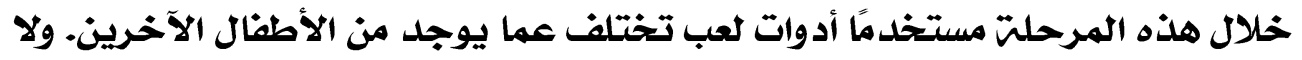

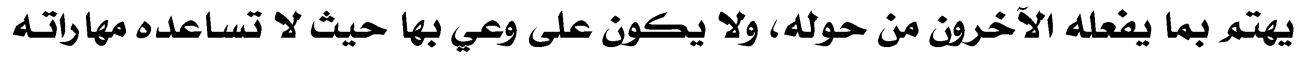

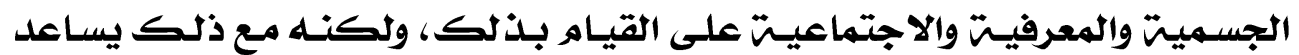

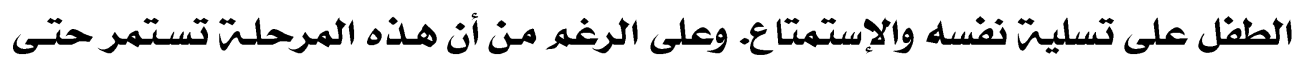

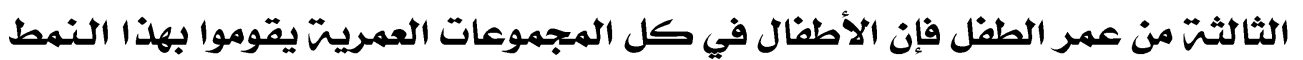
من وقت لآخر.

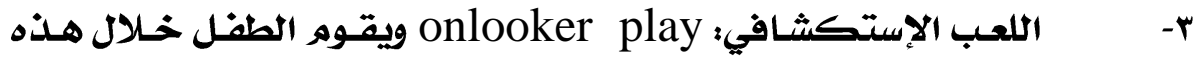

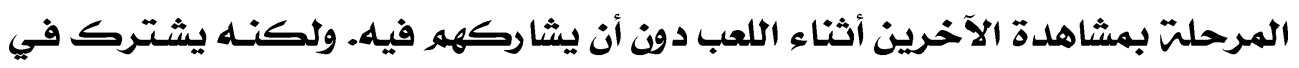

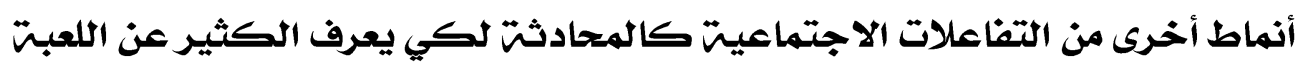

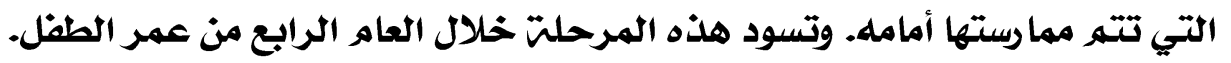

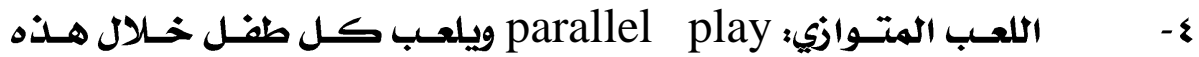

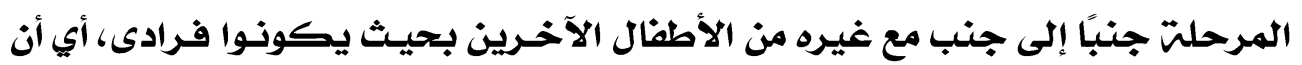

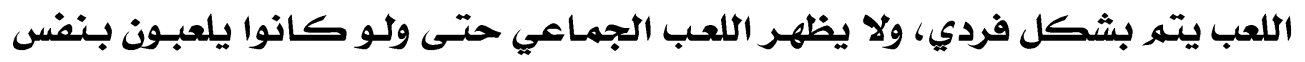

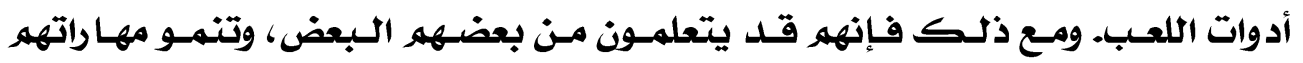

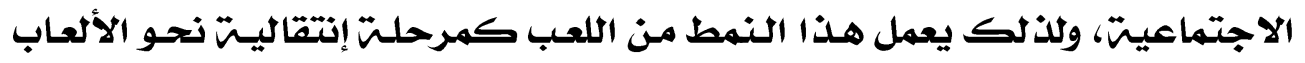

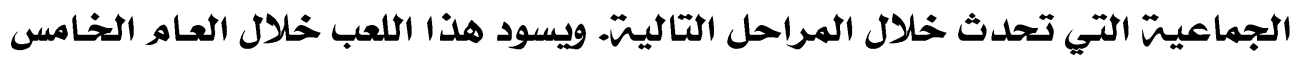

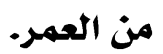

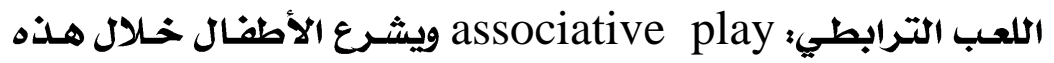
$-0$

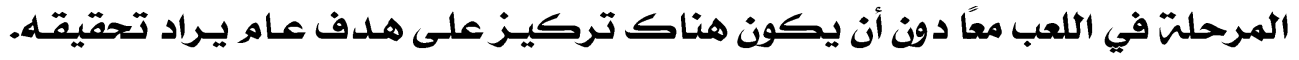

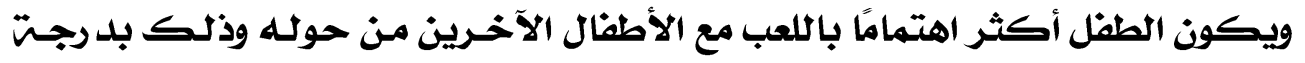

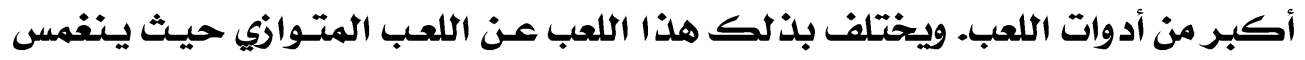

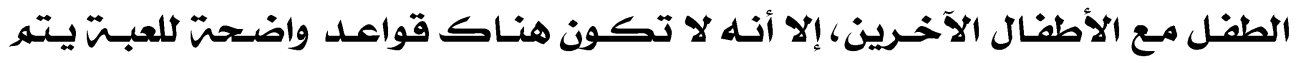

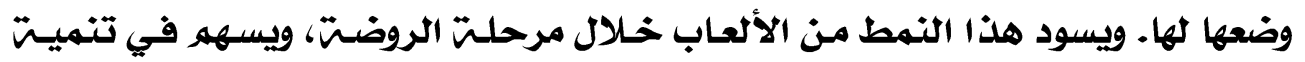
المهارات الالازمت للتعاون، وحل المشكاء ولئات، ونمو اللغتة.

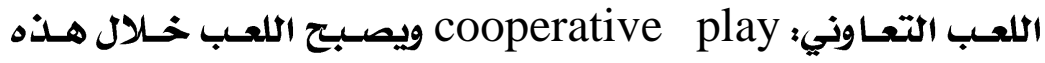
$-7$

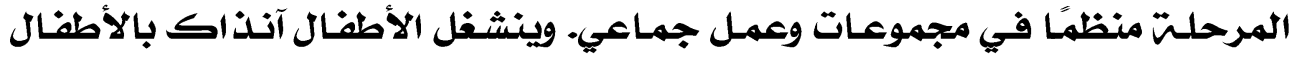




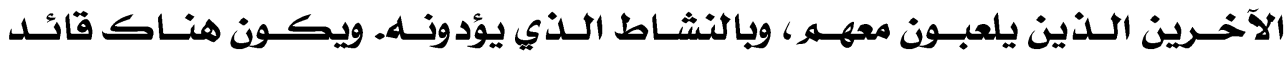

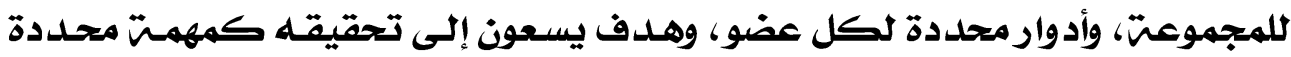

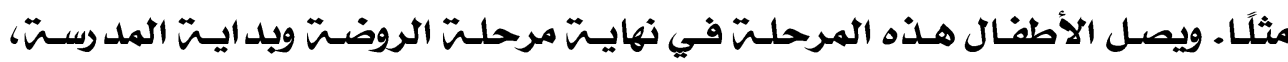

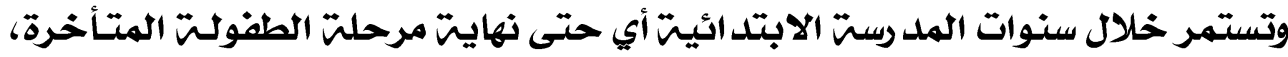
وتتطلب مهارات تنظيميتة، ودرجت معقولتّ من النمو الاجتماعي. ويتهر تكريس تلك

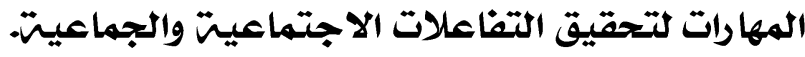

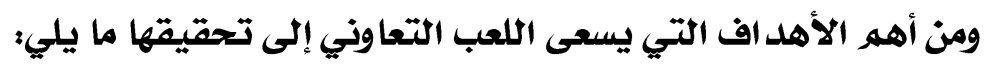

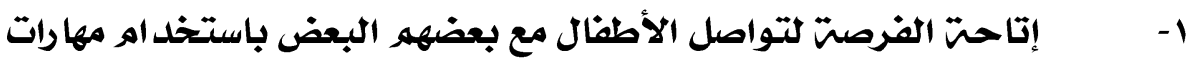
التحدث والإستماع التي تكون قد تطورت لد الديهـه.

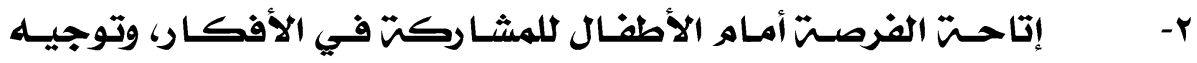

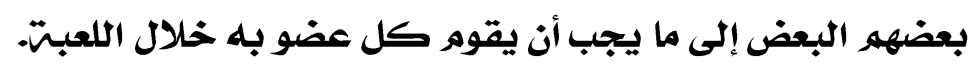

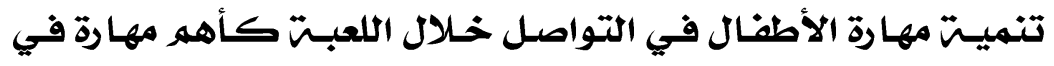
$-r$ اللعب التعاوني.

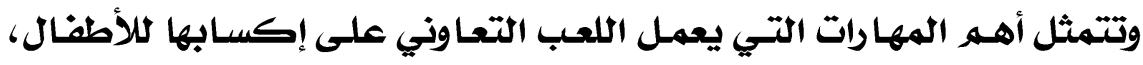

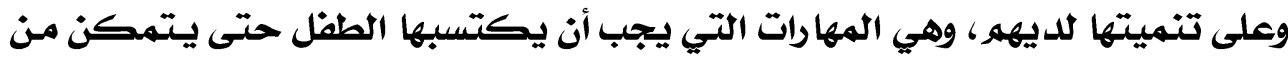

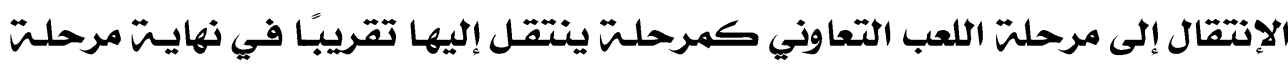

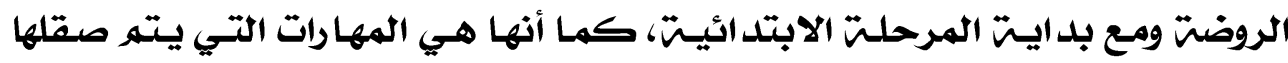

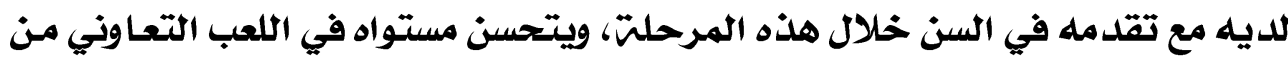

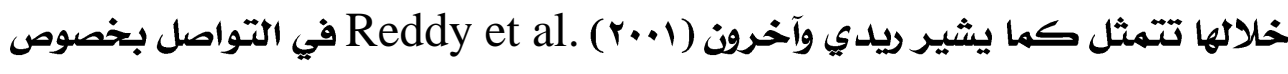

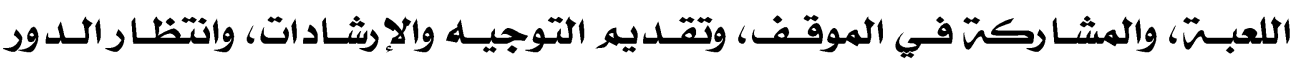

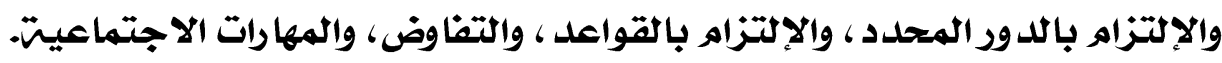

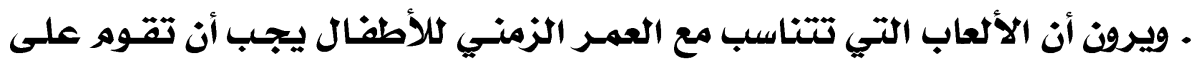

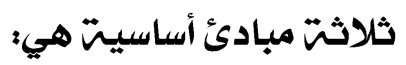

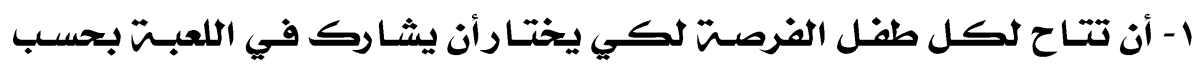
مستوى قد رته.

r- أن تزداد فرص التهب ألعب ومما وست المهارات مع التقده في مستوى اللعبتة.

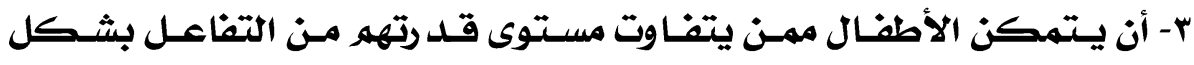

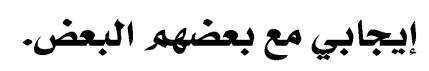

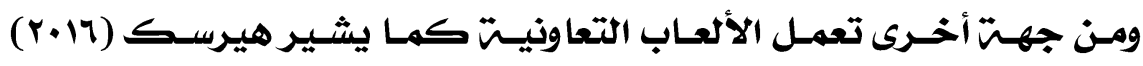

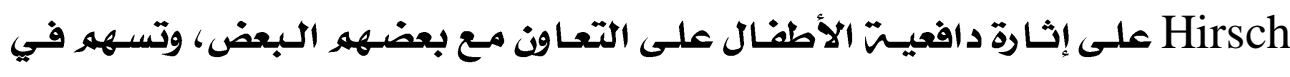

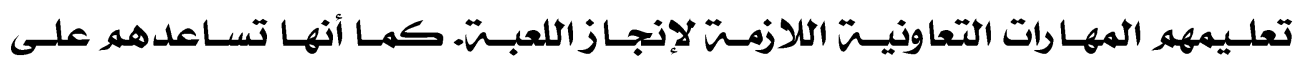

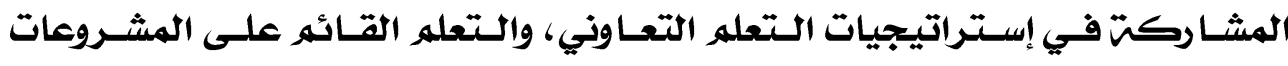

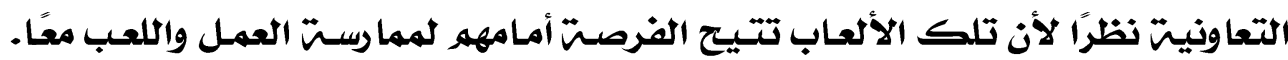


Aronson\& Patnoe وكذلك فإنها تساعدهم كما يشير أرونسون وباتنو (r.11)

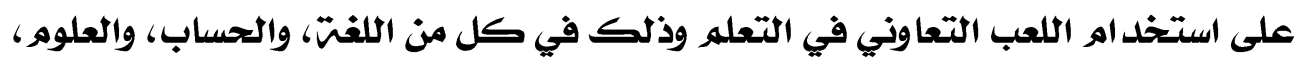

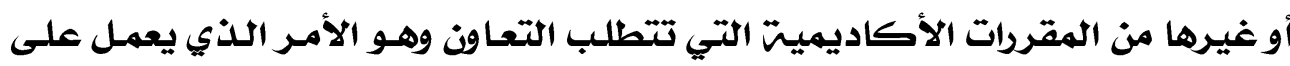

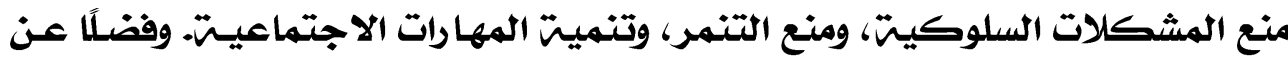

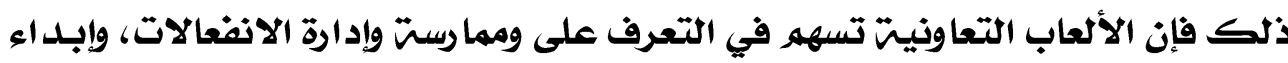

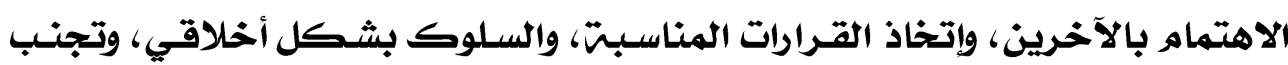

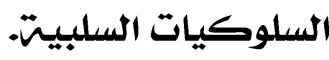

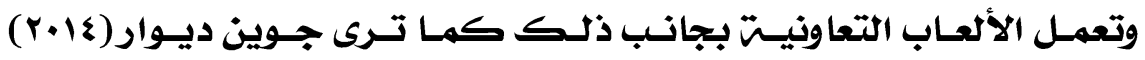

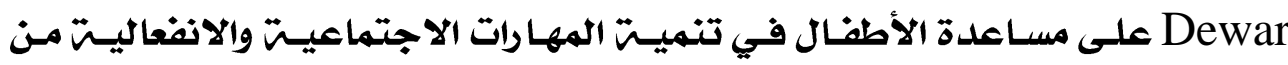

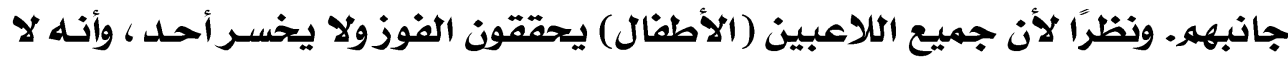

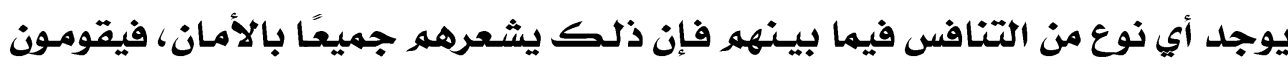

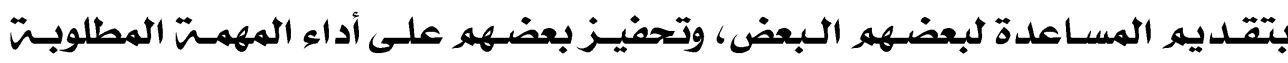

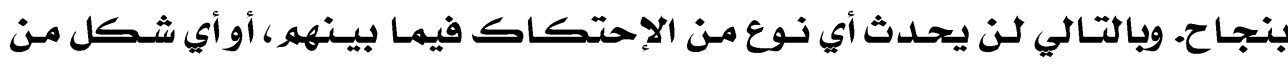

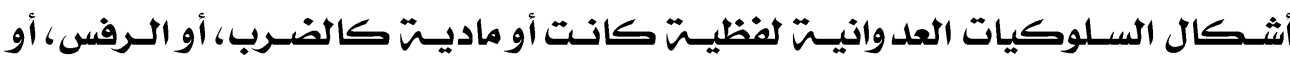

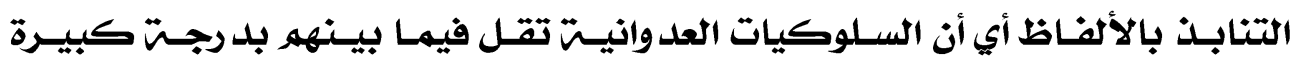

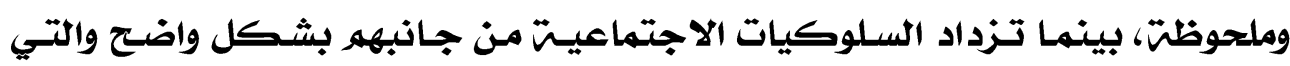

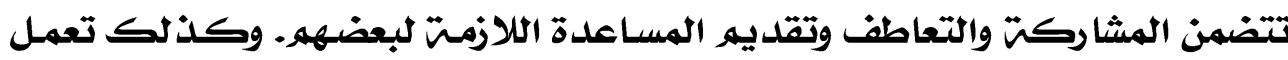

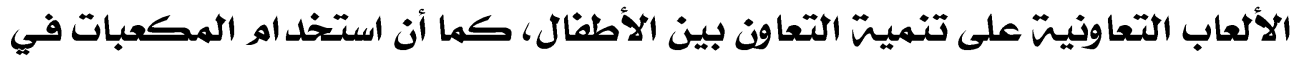

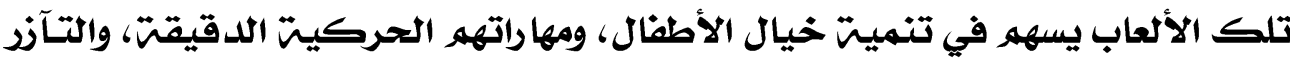

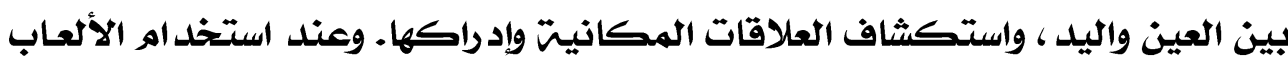

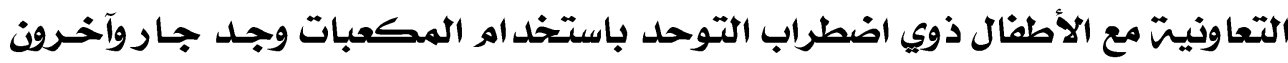

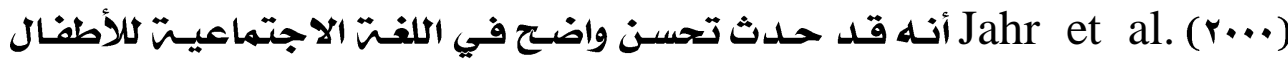

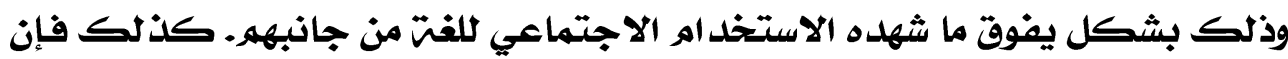

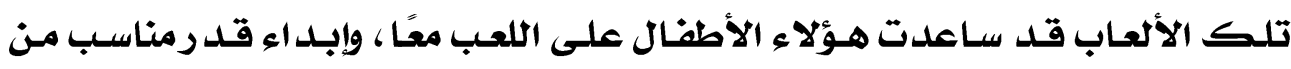

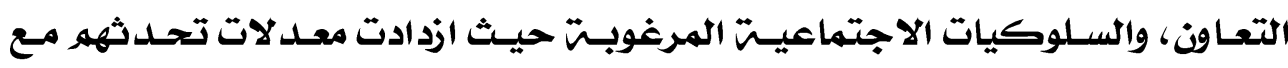

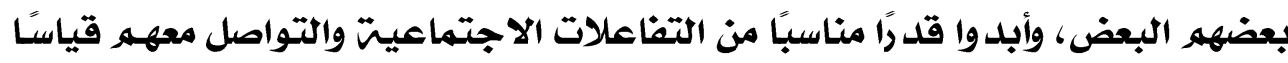

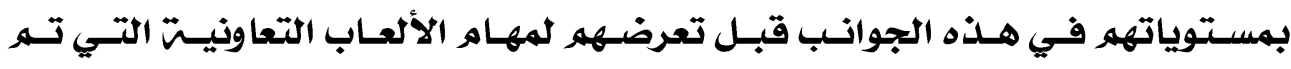

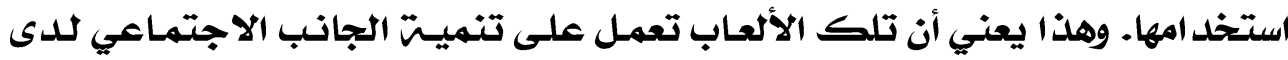

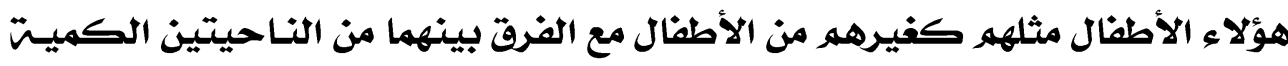

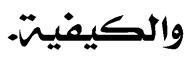

وإذا كانت الألعـاب التعاونيـت تسهـهـ بصـورة أساسيتة في تعليهر الأطفـال

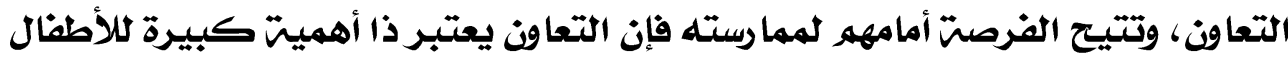

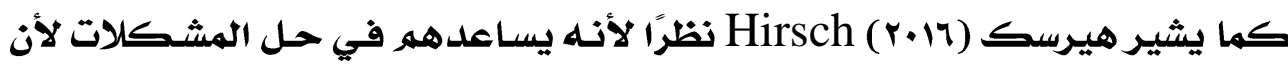


المنطق يؤكلد أن وأسين أي تقديه فكرتين من جانب شخصين أفضل من رأس واحلدة

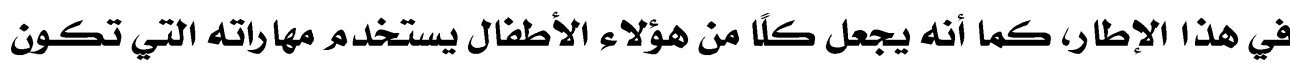

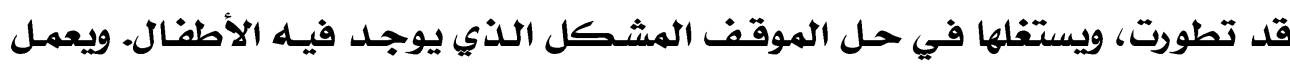

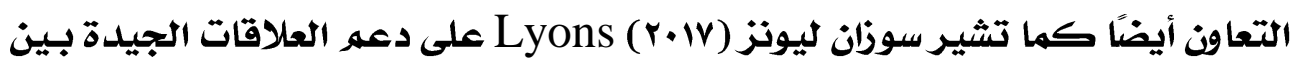

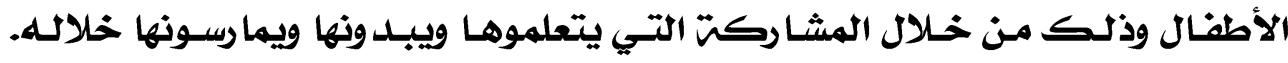

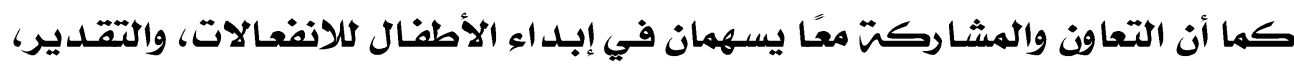

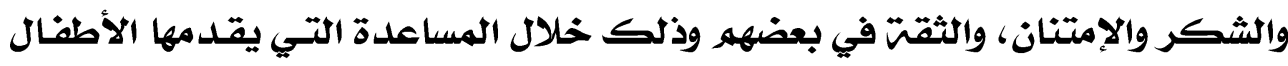

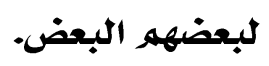

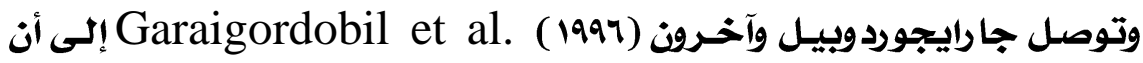

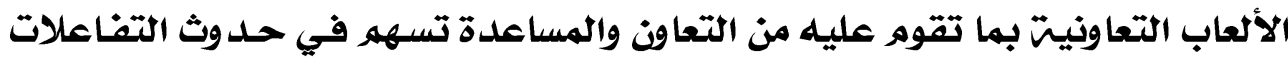

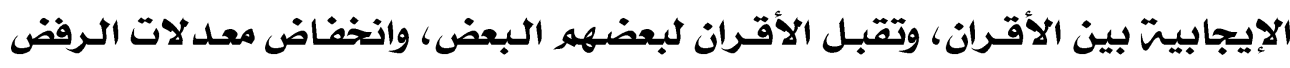

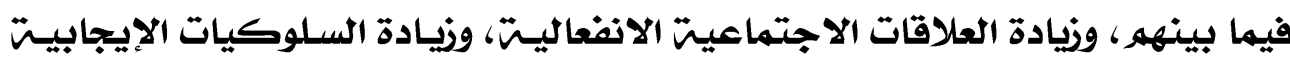

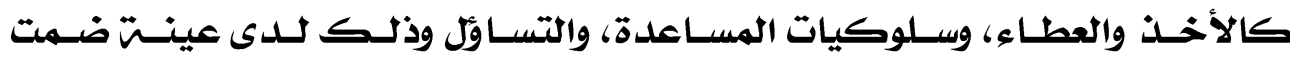

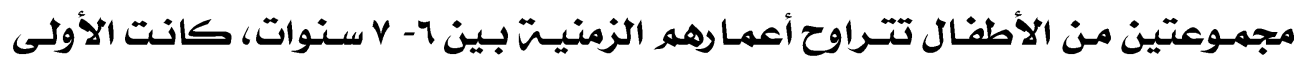

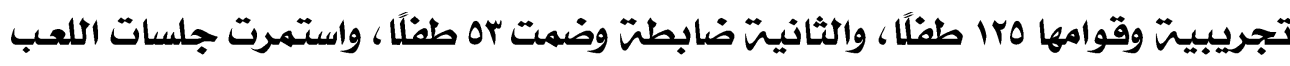

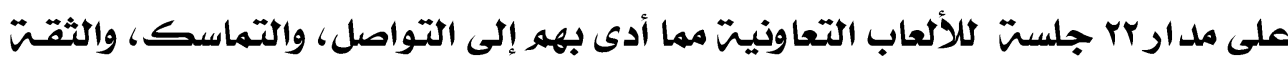

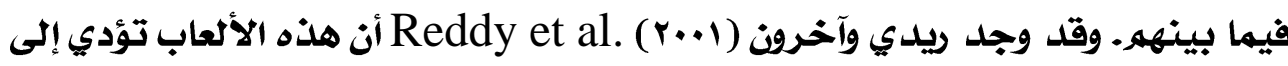

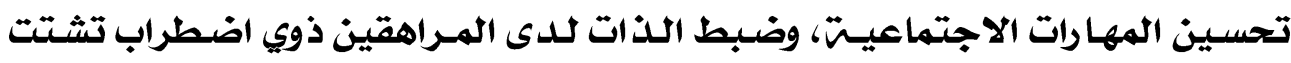

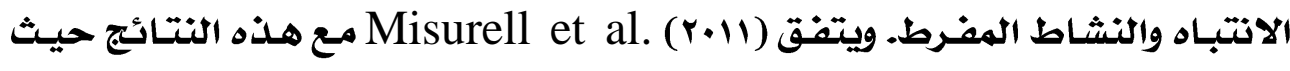

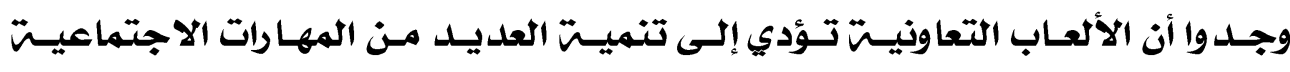

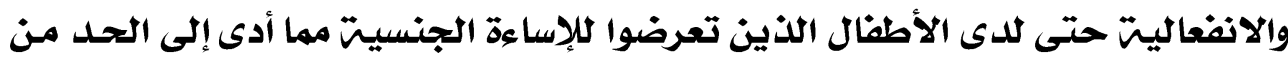

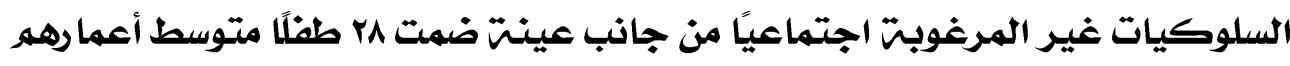

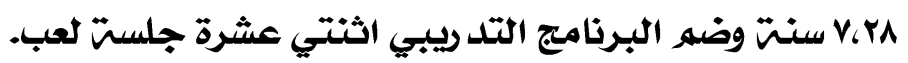

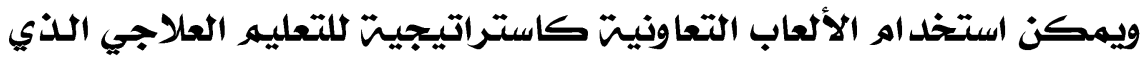

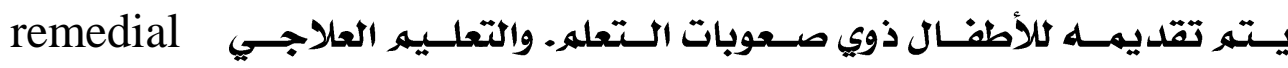

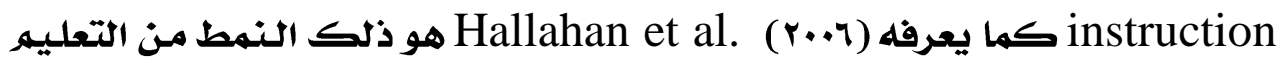

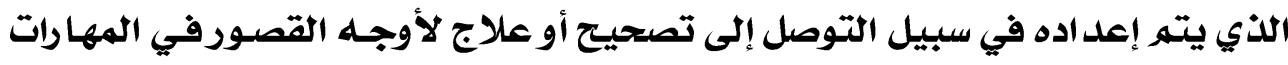

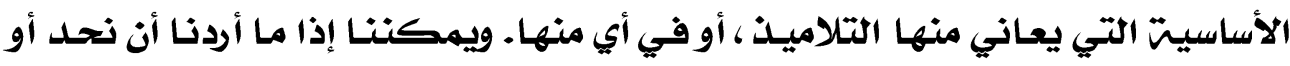

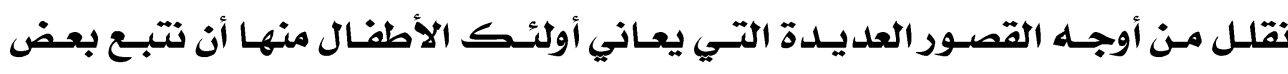

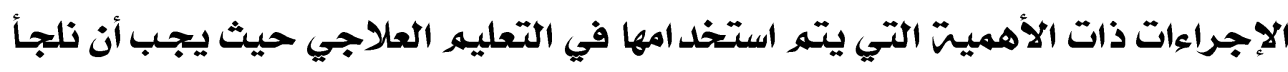

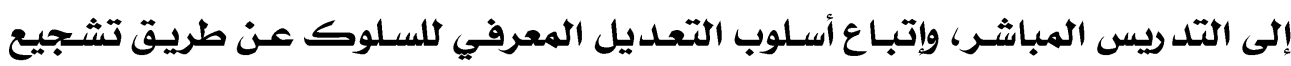

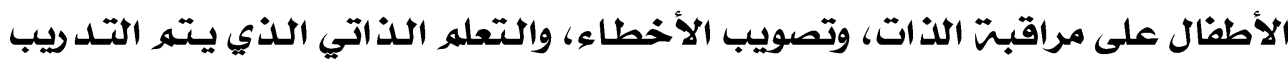

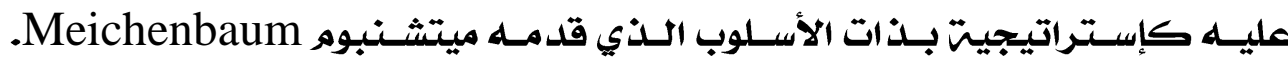




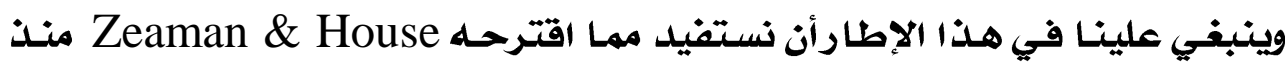

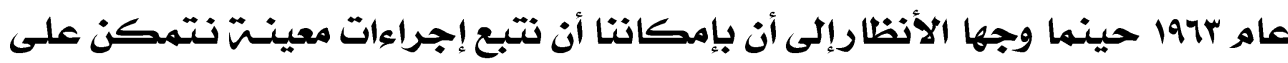

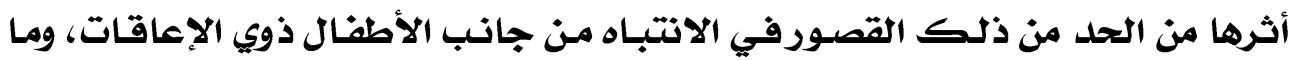

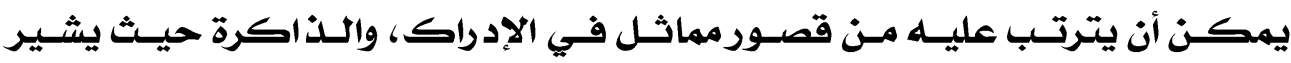

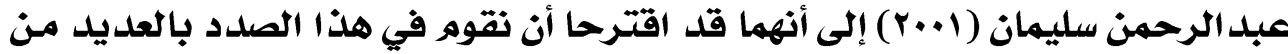

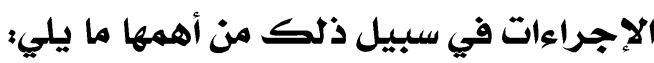

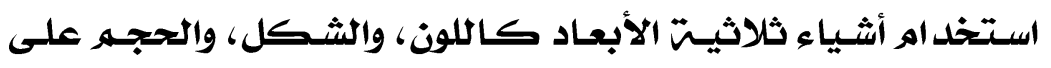

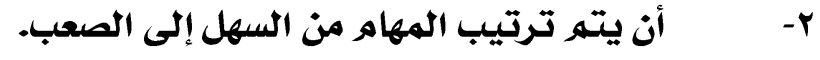

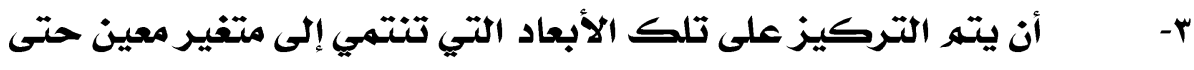

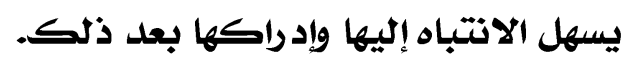

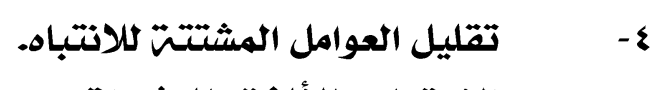
-

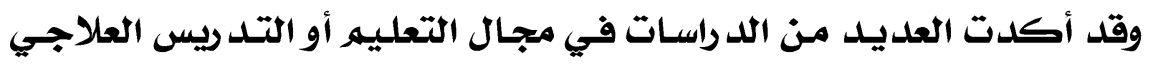

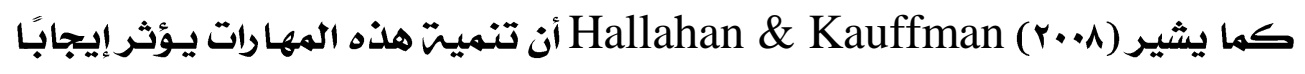

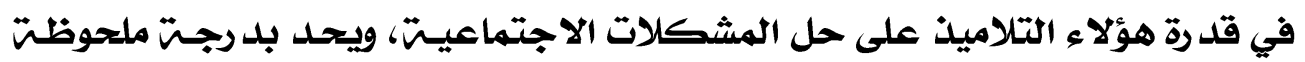

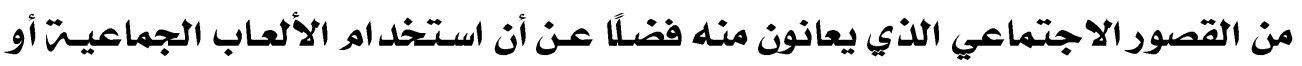

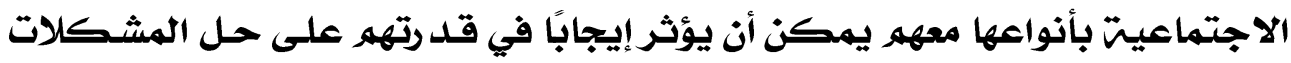

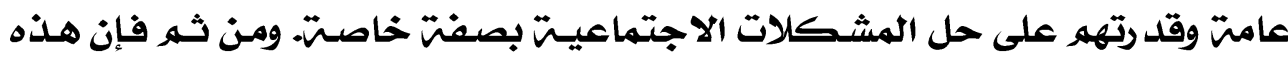

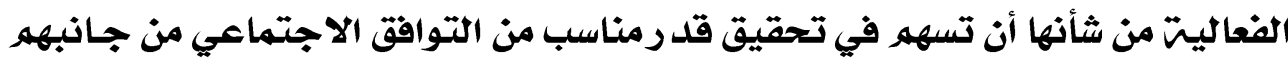
يمكنهه من الاندماج مع الآخرين.

\section{النظريات والنماذج المفسرة للانتباهد}

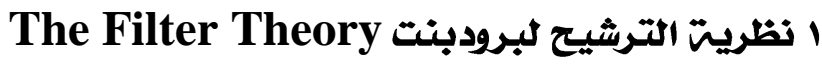

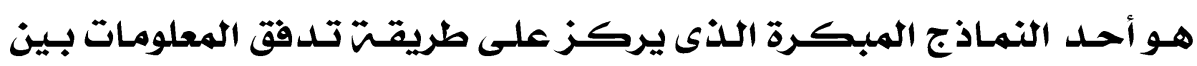

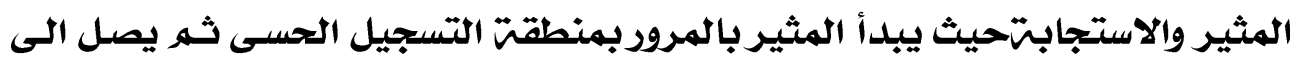

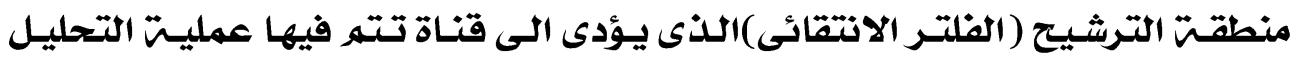

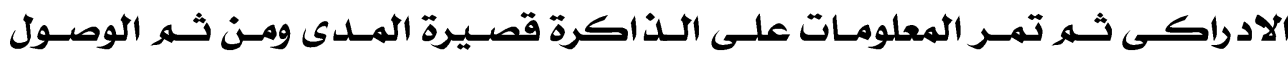
كلاستجابت المطلوبت ( Sternberg, 1999,93).

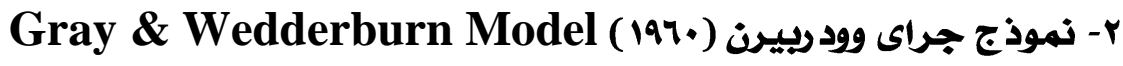

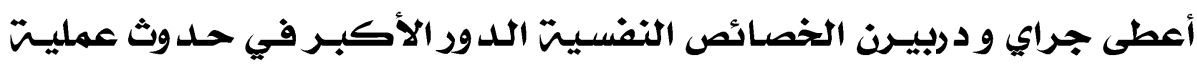

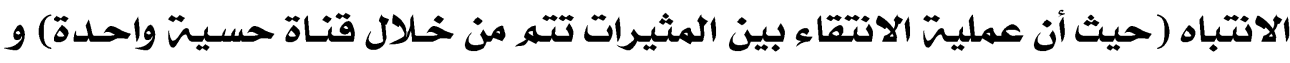


هذا يؤكد أن عمليت استخلاص المعني ذات أهميت في حلدوث عمليـت الانتبـاه (نـوره

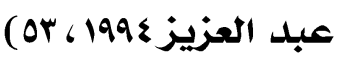

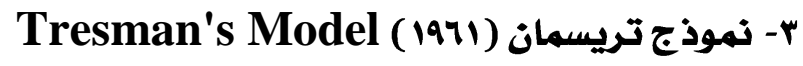

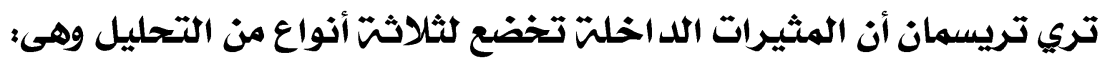

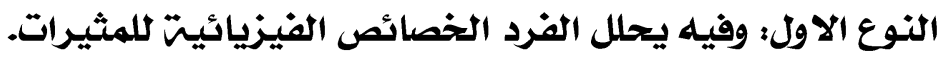

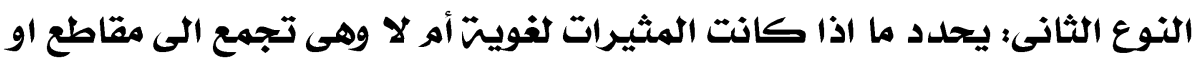
كلمات.

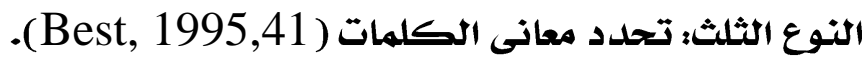

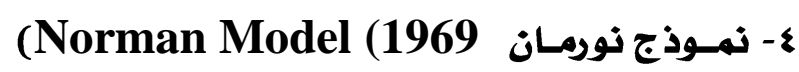

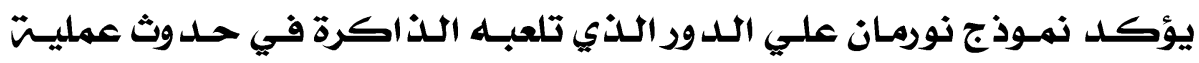

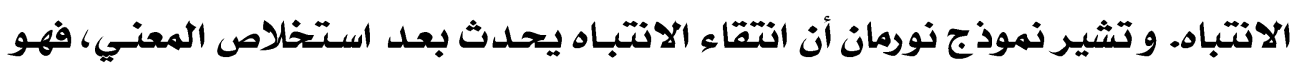

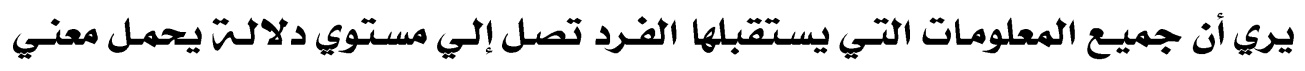

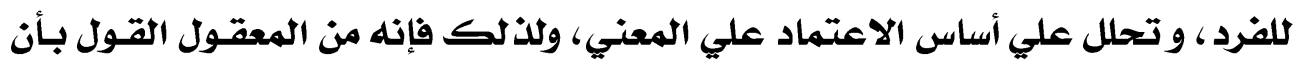

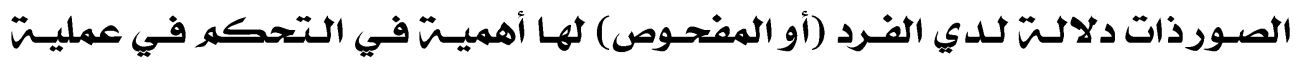

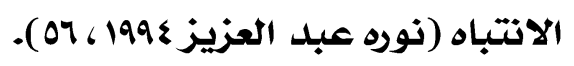

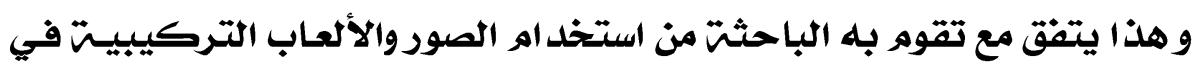

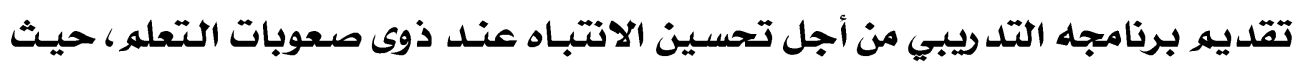

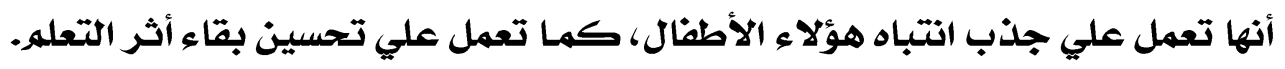

دراسات وبحوث السابقنت: دواستئ (199r)

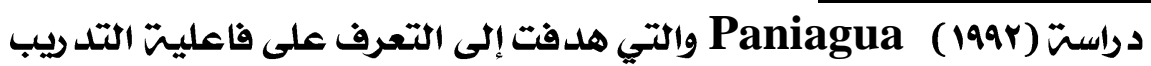

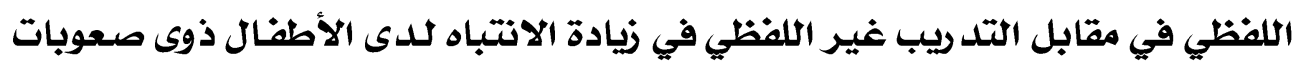

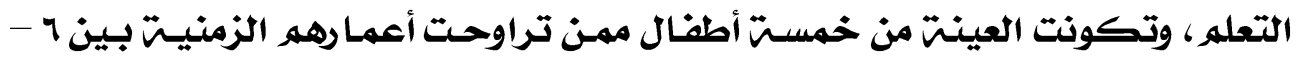

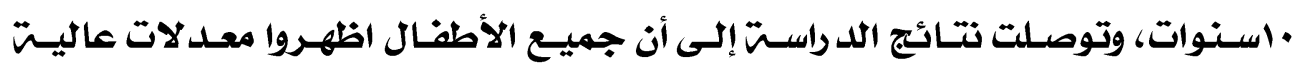

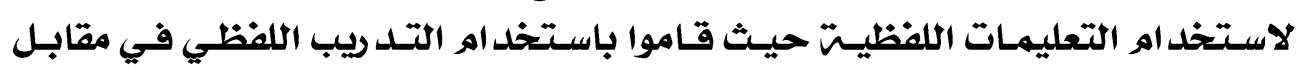

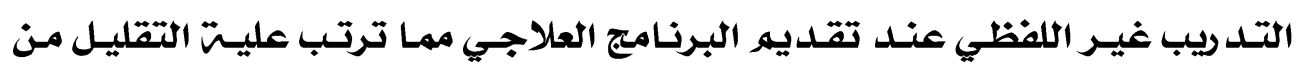
أعراض قصور الانتباه والذي انعكس على على مستوى أداء الأطفال.

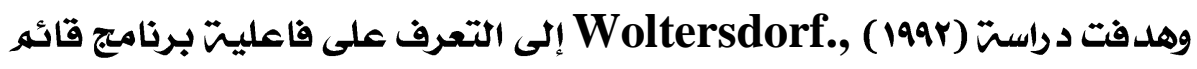

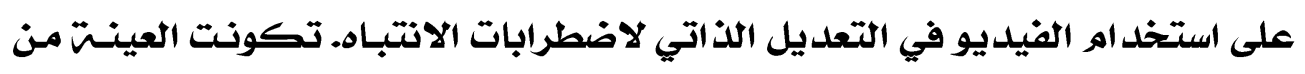

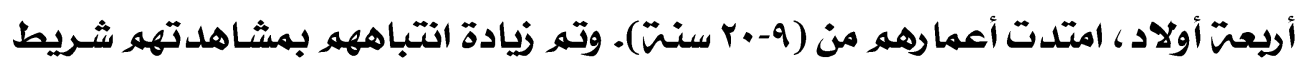

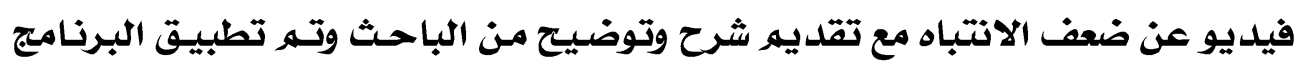

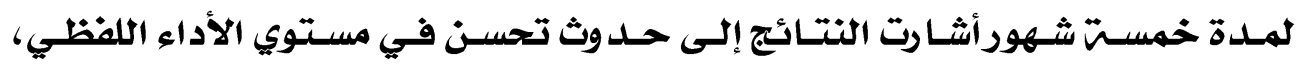




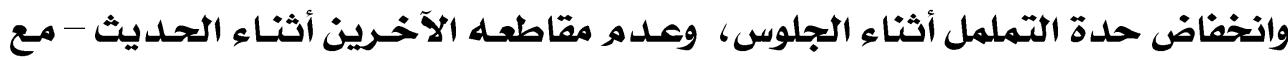

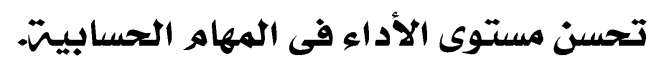

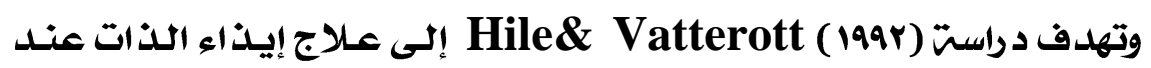

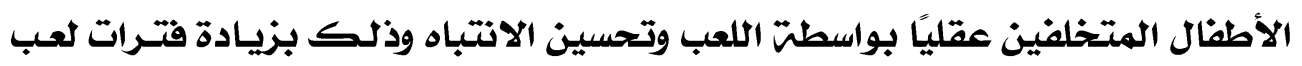

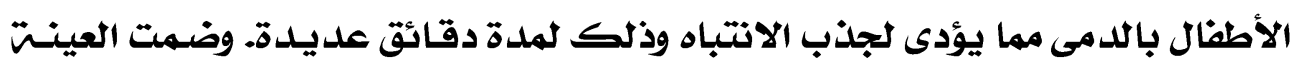

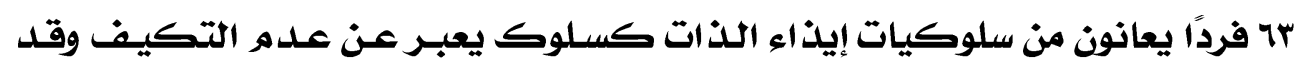

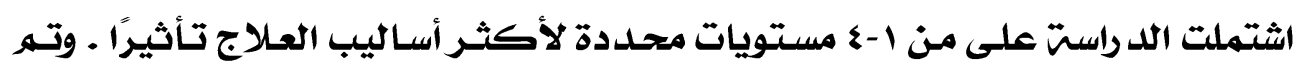

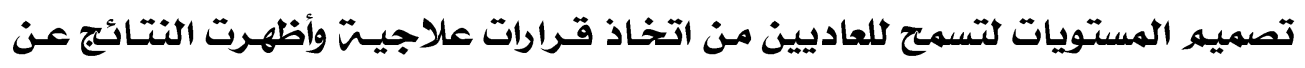

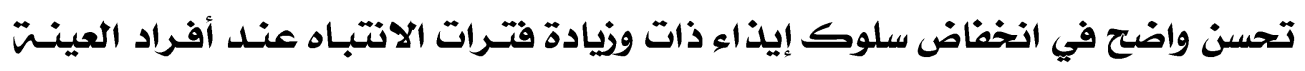
وذلك بزيادة فترات اللعب.

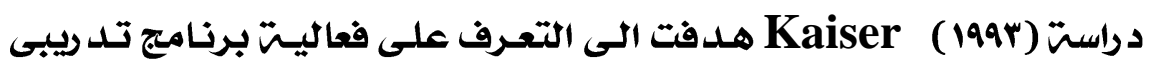

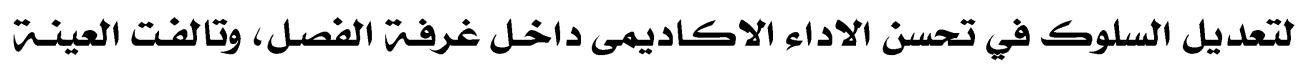

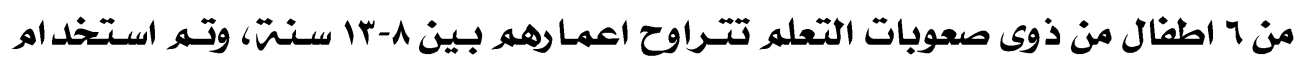

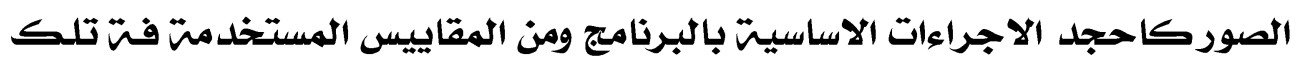

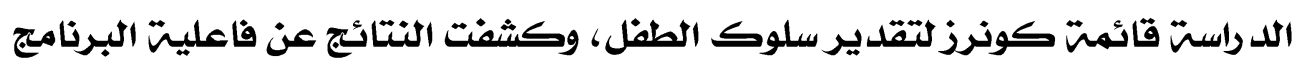
في حلدوث زيادة في تركيز الانتباة من جانب افراد العينت للمهاهر المختلفتر.

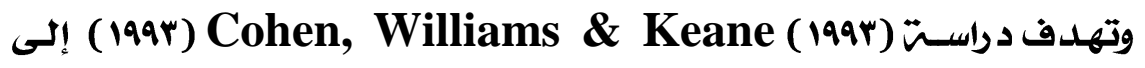

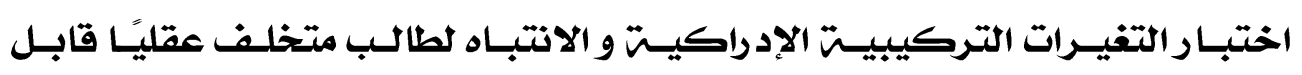

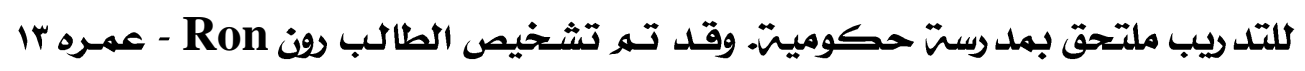

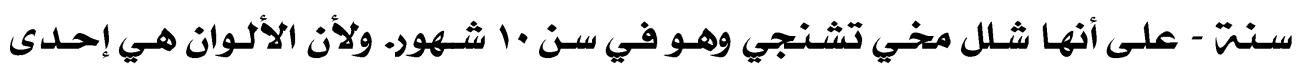

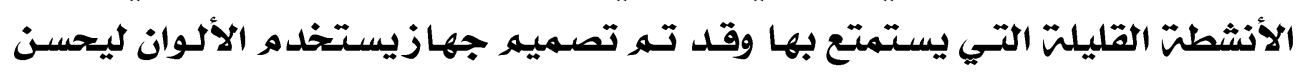

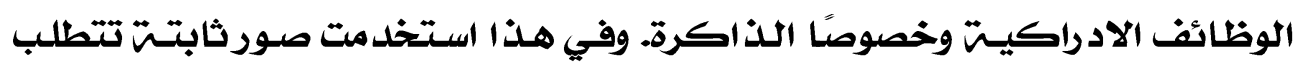

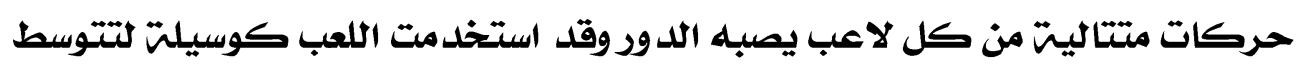

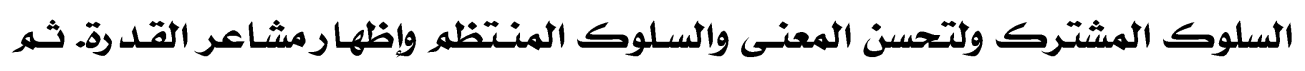

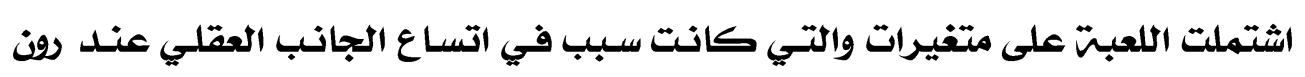

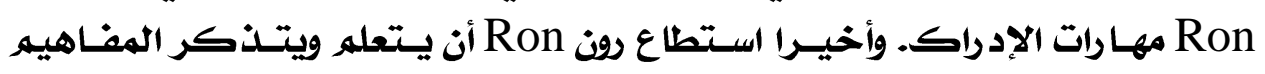

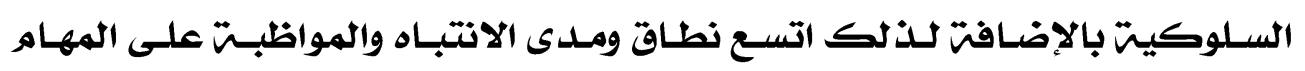

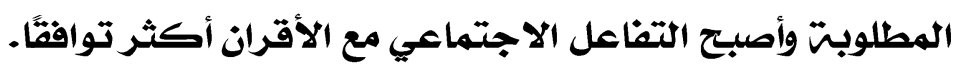

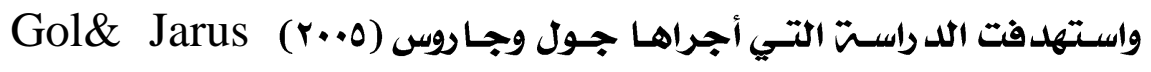

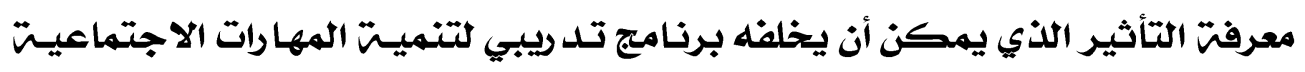

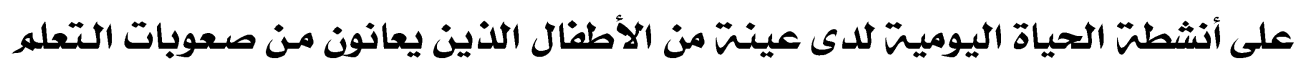

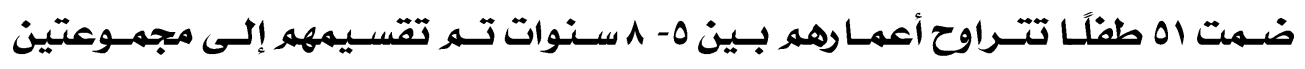

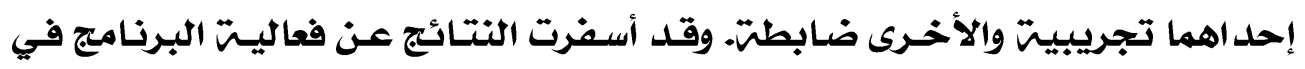




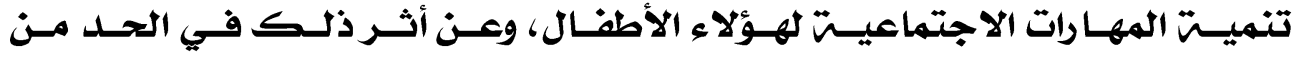

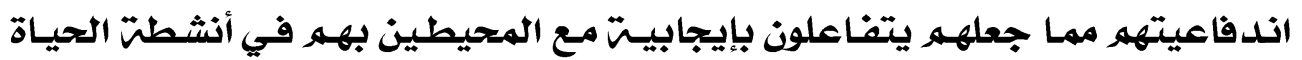

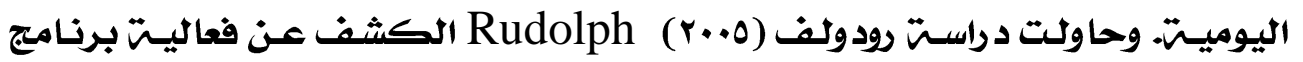

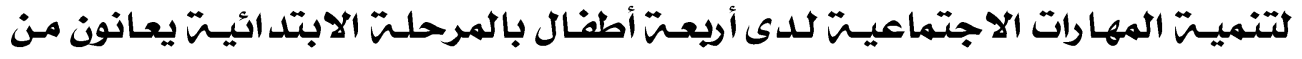

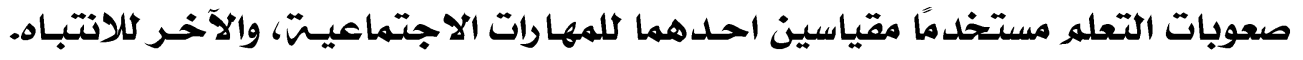

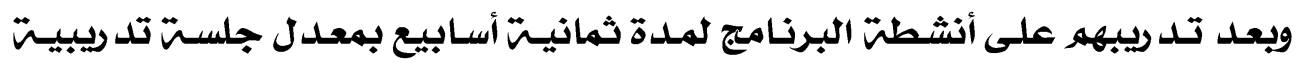

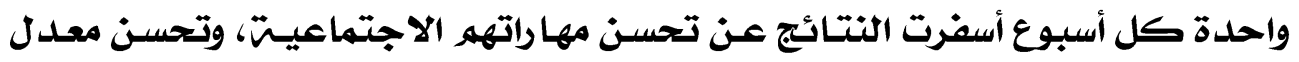
الانتباه من جانبهه.

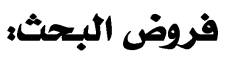

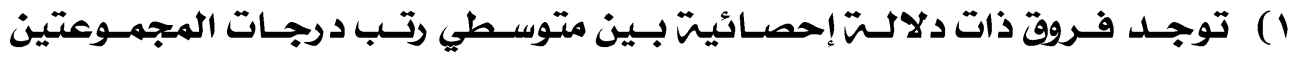

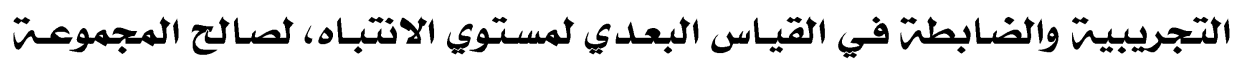

التجريبييت.

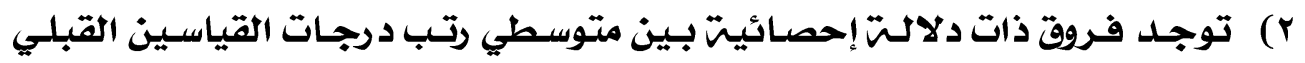

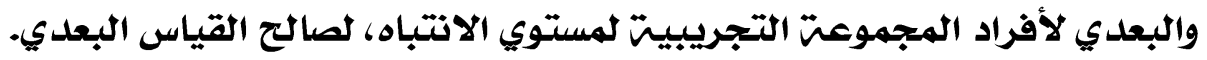

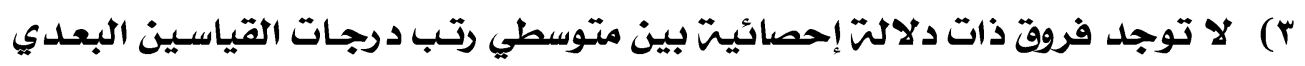

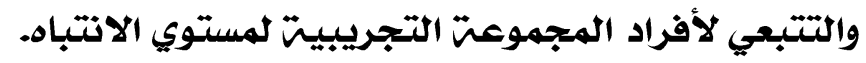

$$
\text { منهج البحثاءع: اعتمد البحث البحث الحالي علي المنهج التجريبي. }
$$

$$
\text { عينت البحث }
$$

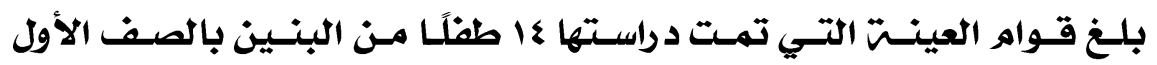

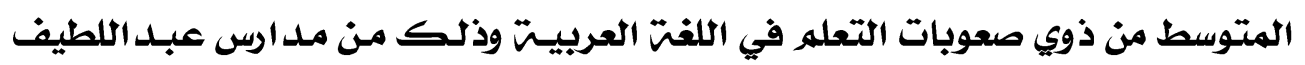

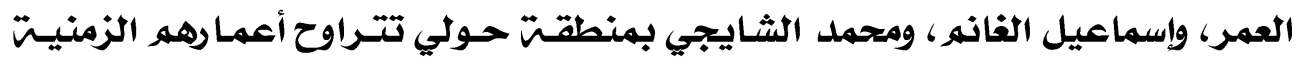

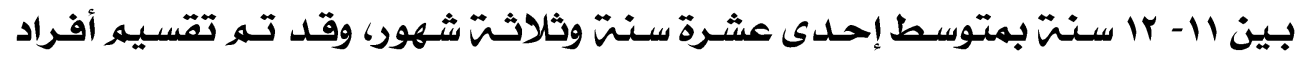

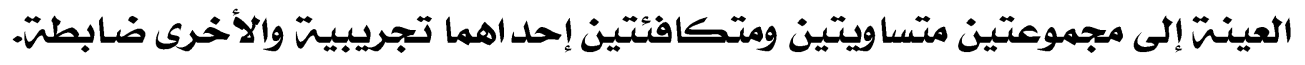

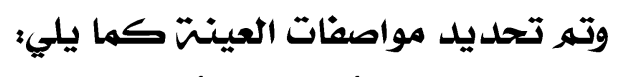

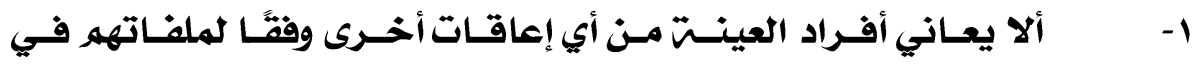
المدل وستّ.

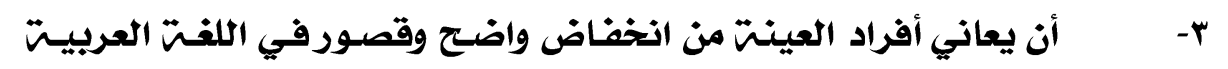
وفقًا لد رجاتههر المد ونت في سجاتلات المد رستّ. 


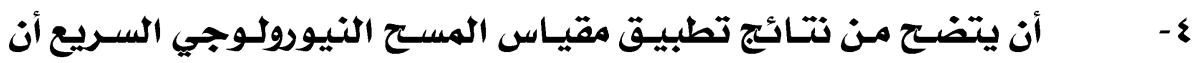

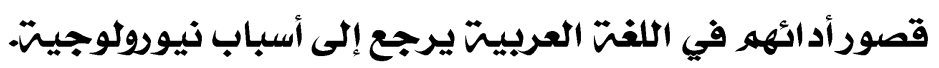

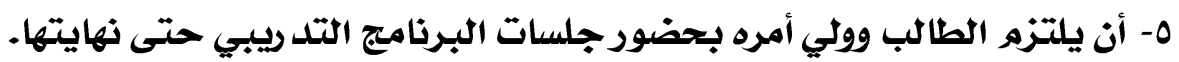

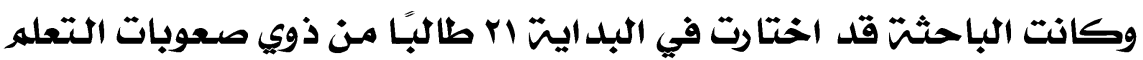

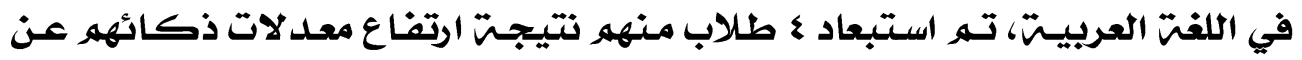

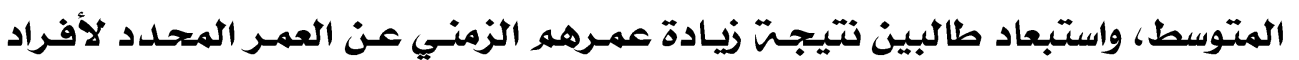

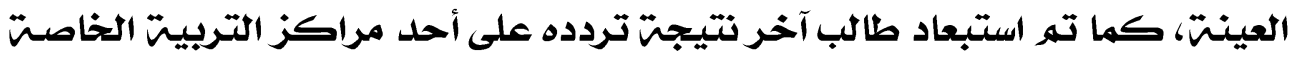

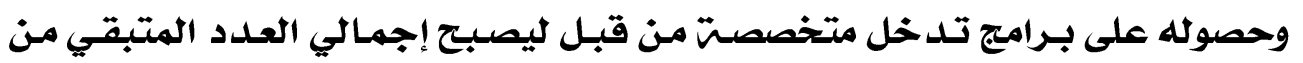

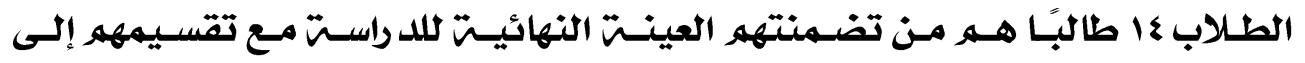

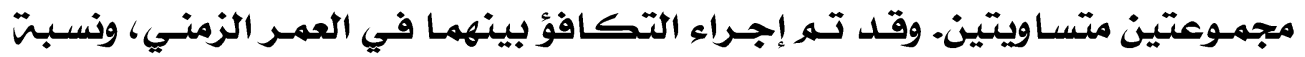

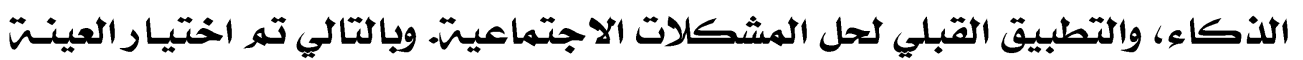

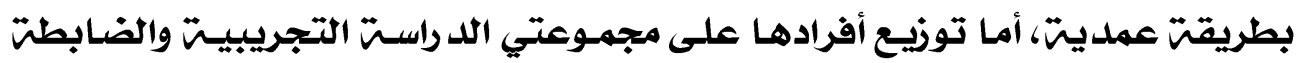

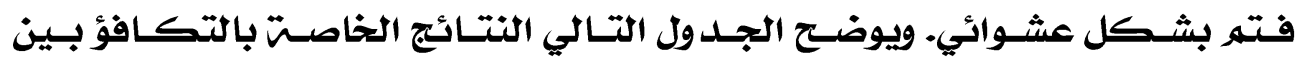
مجموعتي الد راستة.

جد ول (1)

دلالت الفروق بين متوسطي رتب درجات المجموعتين التجريبيت والضابطت في

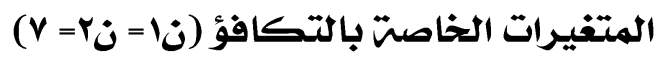

\begin{tabular}{|c|c|c|c|c|c|c|c|}
\hline الدلالت & Z & W & $\mathrm{U}$ & مجموع & متوسط & الهجموعت & المتغير \\
\hline غير & $.0 \leqslant r_{-}$ & $\left\{r_{6} \ldots\right.$ & $196 .$. & $\begin{array}{l}\Delta \Lambda_{6} \ldots \\
\sum V_{6} \ldots\end{array}$ & $\begin{array}{l}\text { A.ra } \\
7 . \mathrm{rI}\end{array}$ & الضتجريبيتت & العمر الزمني \\
\hline غير & . & 0.60. & rr.O. & $\begin{array}{l}0 \leqslant .0 . \\
0.60 .\end{array}$ & $\begin{array}{l}\text { V.VA } \\
\text { V.rI }\end{array}$ & الضابطريبيت & مستوى الذكاء \\
\hline غير & $.610-$ & $\left\{V_{6} \ldots\right.$ & $196 .$. & $\begin{array}{l}\Delta \Lambda_{6} \cdots \\
\sum V_{6} \cdots\end{array}$ & $\begin{array}{l}\text { A.ra } \\
7 . \mathrm{YI}\end{array}$ & الضابطريبيت & الاجشتهاعلات \\
\hline
\end{tabular}

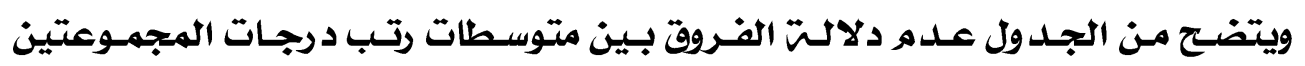

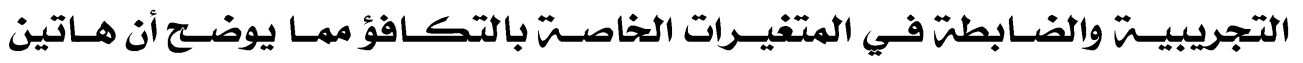

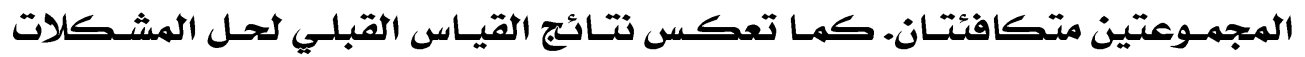

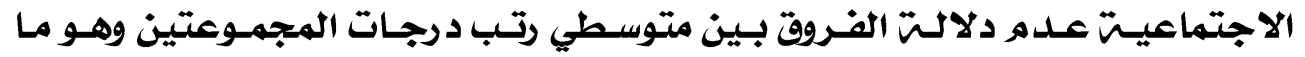

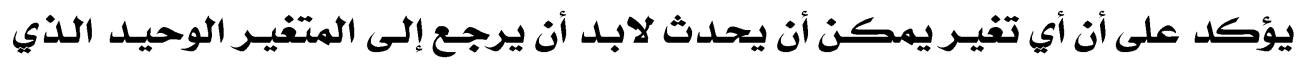

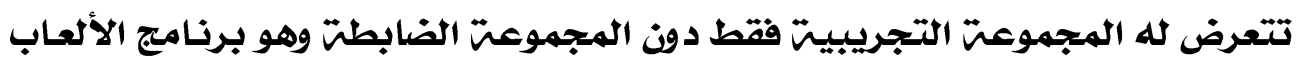
التعاونيت المستخده في الد راستّ. 


\section{أدوات البحث أبحث}

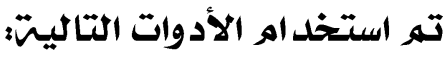

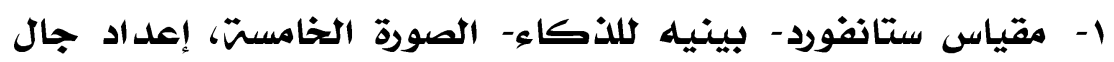

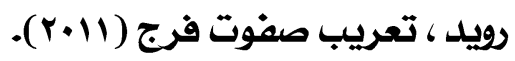

r- اختبار المسح النيورولوجي السريع، إعداد مارجريت موتي وآخرون،

$$
\text { تعريب عبد الوهاب كامل (1999 ). }
$$

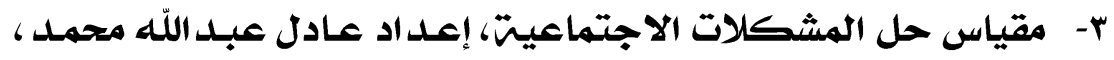

$$
\text { وشيخت الأنصاري. }
$$

§- برنامج الألعاب التعاونيتة، إعداد عادل عبدالله محمد، وشيختر

الأنصاري.

$$
\text { خطوات البحث }
$$

ته إتباع الخطوات التاليت في سبيل القياه بهذه الد راست وتثنيذهاء

ا- تحديد وإعداد الأدوات المستخدمتة، والتأكد من صلاحيت مقياس حل

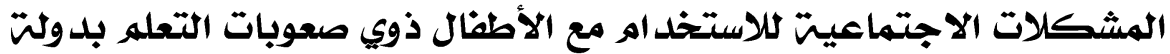

$$
\text { الكويت وذلك بحساب خصائصه السيكومتريتة. }
$$

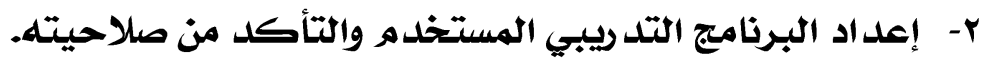

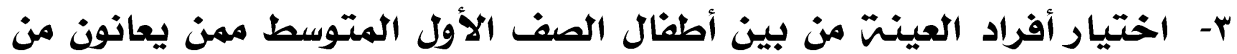

$$
\text { صعوبات التعله في اللغت العربيت. }
$$

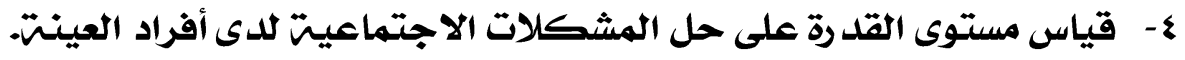

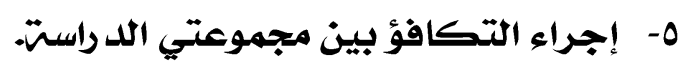

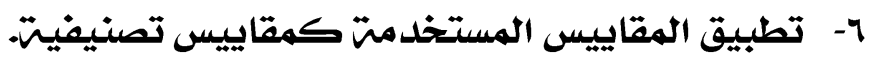

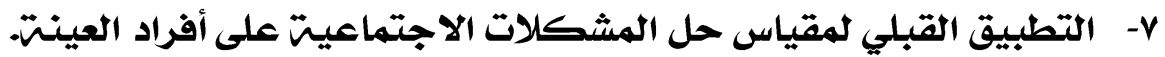

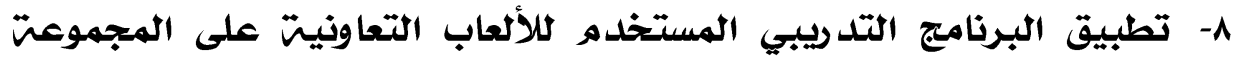

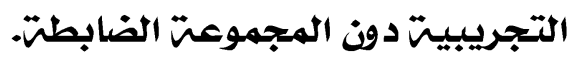

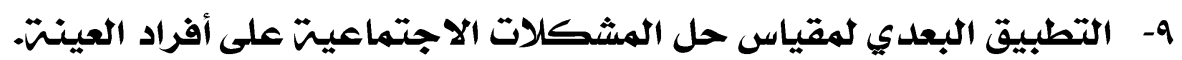

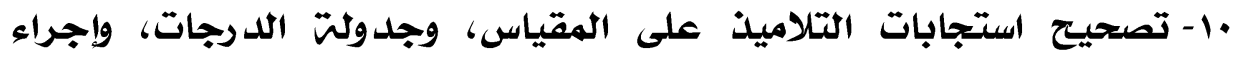

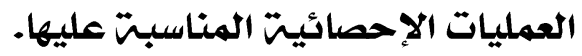

1ا-صياغت بعض التوصيات والمقترحات التي نبعت مما أسفرت عنه هذه

$$
\text { الأسائيب الإحصائيت المستخدل الرامنت من نتائج. }
$$

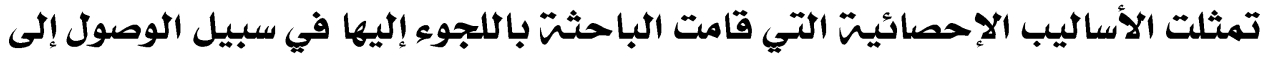

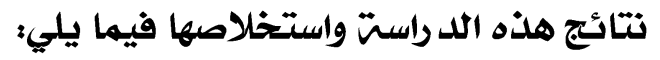




$$
\begin{aligned}
& \text { - اختبارمان - وتيني (Uann- Whitney (U) - } \\
& \text { - اختبارولكوكسون -Wilcoxon (W) - }
\end{aligned}
$$

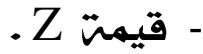

$$
\text { نتائج البحث وتفضيرهاء }
$$

ينص الفرض الأول على أنه "توجد فروق ذات دالاتلت إحصائيت بين

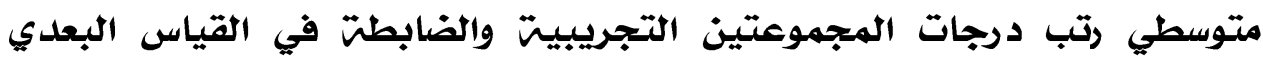

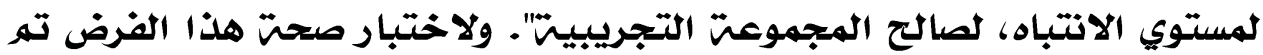

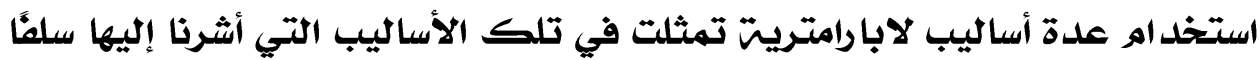

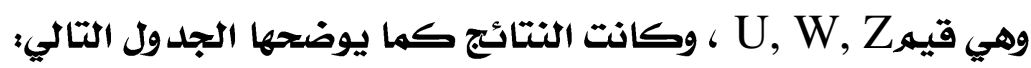

\begin{tabular}{|c|c|c|c|c|c|c|c|c|}
\hline اتجاهها & الدلالت & Z & W & $\mathrm{U}$ & الرتب & الرتب & هو & المججموعت \\
\hline التجريبييت & $\because \cdot 1$ & $\begin{array}{l}- \\
\text { T.ITE }\end{array}$ & $\mathrm{rA}$ & $\cdots$ & $\begin{array}{l}r_{6} \ldots \\
r_{6} \ldots\end{array}$ & $\varepsilon_{6} \cdot$. & $\begin{array}{l}1 . ., 18 \\
1 \mathrm{rq}, \mathrm{rq}\end{array}$ & التجريبيتت \\
\hline
\end{tabular}

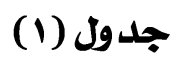

قيه U, W, Z ودلالتها للفرق بين متوسطات رتب درجات

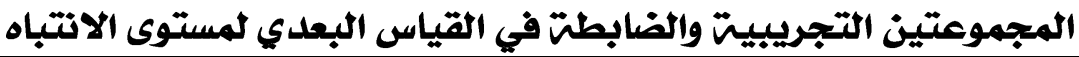

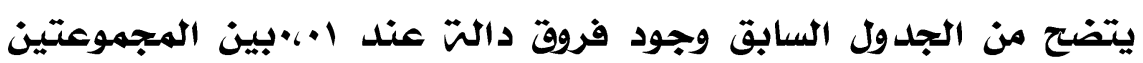

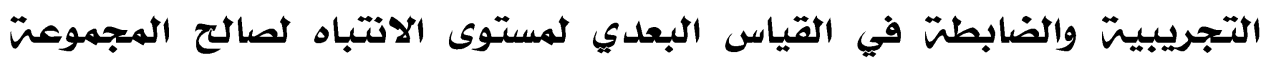

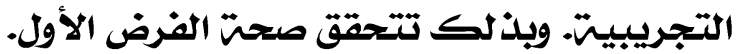

$$
\begin{aligned}
& \text { (r) نتائج الفرض الثاني: }
\end{aligned}
$$

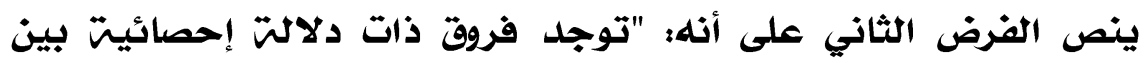

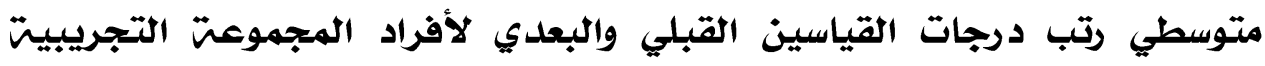

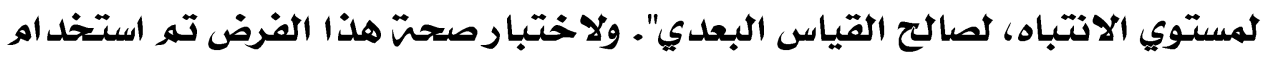

\begin{tabular}{|c|c|c|c|c|c|c|c|c|}
\hline اتجاهها & الدעلت & $\mathrm{Z}$ & $\mathrm{W}$ & $\mathrm{U}$ & مج الرتب & مر الرتب & هو & القياس \\
\hline البعدي & $\cdot 6 \cdot 1$ & $r_{6}(\varepsilon)-$ & $r \wedge$ & صفر & $w_{6} \cdot \ldots$ & $116 .$. & Irq.rq & البعدي \\
\hline
\end{tabular}

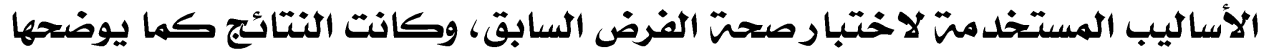

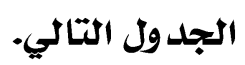

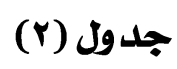

قيه U, W, Z ودلالتها للفرق بين متوسطي رتب درجات

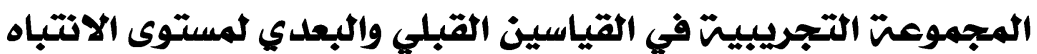




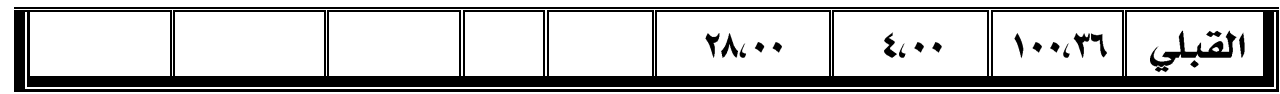

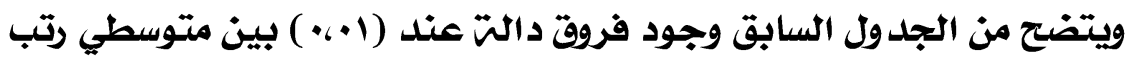

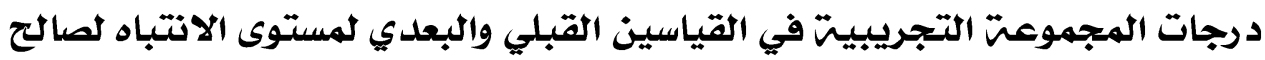
القياس البعدي. وبذلك تتحقق صحت الفرض الفرئر الثاني.

(ع) نتائج الفرض الرابع:

ينص الفرض الرابع على أنه: "لا توجل فروق ذات دات دلالت إحصائيت بين

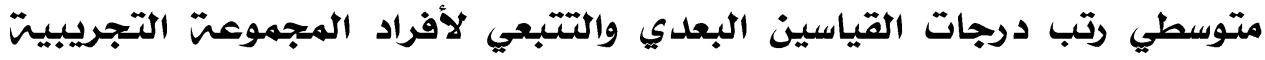
لمستوي الانتباه". ولاختبار صحت هذا الفرض تم استخداه نفس الأساليب المستخدمت لاختبارصحت الفرض السابق، وكانت النتائج كما يوضحها الجدول

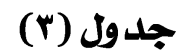

قيه U, W, ودلالتها للفرق بين متوسطي رتب درجات

المجموعت التجريبيت في القياسين البعدي والتتبعي لمستوى الانتباه

\begin{tabular}{|c|c|c|c|c|c|c|c|c|}
\hline اتجاهها & الدلעلت & $\mathrm{Z}$ & $\mathrm{W}$ & $\mathrm{U}$ & مج الرتب & مر الرتب & هر & القياس \\
\hline & غير دالت &.$(0 \leqslant 1-$ & $\varepsilon V$ & 19. & $\begin{array}{l}\Delta \Lambda_{6} \ldots \\
\Sigma V_{6} \ldots\end{array}$ & $\begin{array}{l}\text { A.ra } \\
7 . \mathrm{RI}\end{array}$ & $\begin{array}{l}1 \mathrm{rq} . \mathrm{rq} \\
1 \mathrm{rq} .91\end{array}$ & التبتبعي \\
\hline
\end{tabular}

ويتضح من الجدول السابق عده وجود فروق دالت بين متوسطي رتب درجات

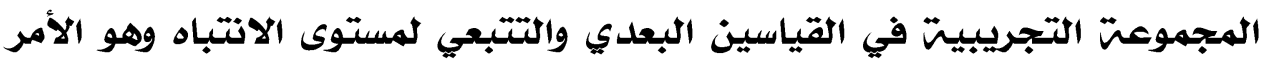
الذي يحقق صحتم الفرض الرابع.

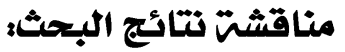

يعد الانتباه من أهه العمليات العقليت التي تلعب دورًا مهمًا في النمو المعرفي

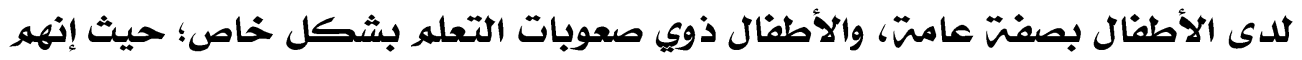

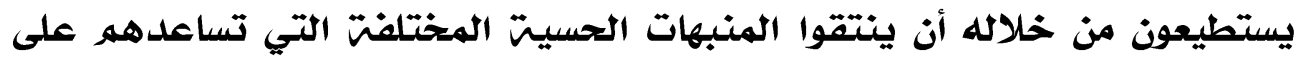

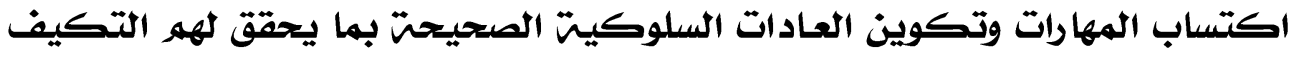
مع البيئتن المحيطت بهه. ويعتبر الانتباه عمليت وظيفيت في الحياة العقليتة، تقوه

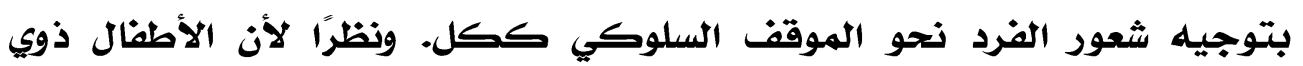

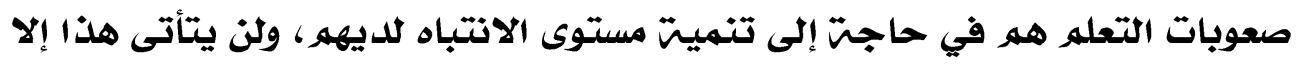

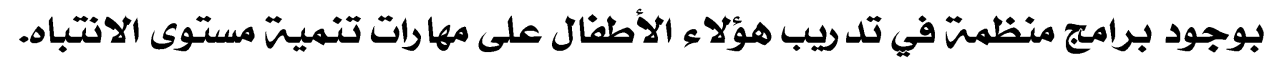

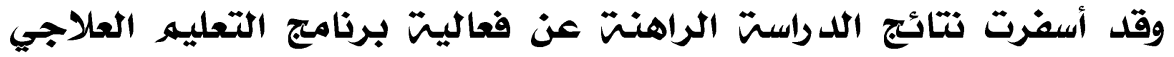
المستخده في تنميت مستوى الانتباه لأطفال الصف الخامس الابتدائي ممن يعانون من صعوبات التعله، حيث وجدت فروق دالتّ عند (1+؛ ) بين متوسطي رتب درجات الهات 
المجموعتين التجريبيت والضابطت في القياس البعلدي لمستوى الانتباه لصالج

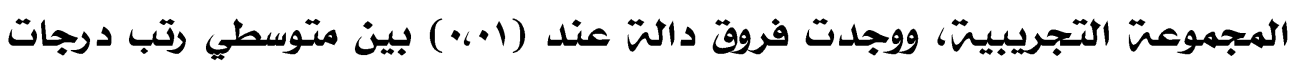

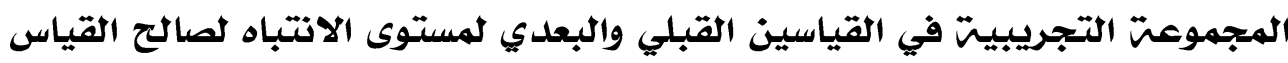

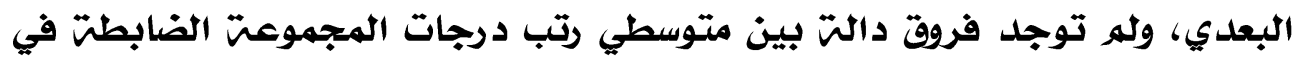
ذات القياسين، ولا بين متوسطي رتب درجات المجموعت التجرئ دريبيت في في القياسين البعدي والتتبعي.

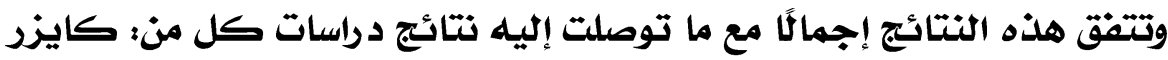

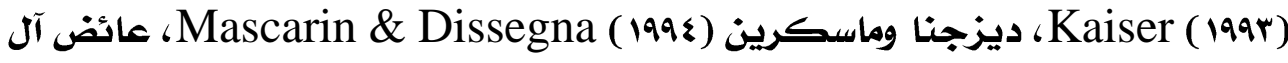

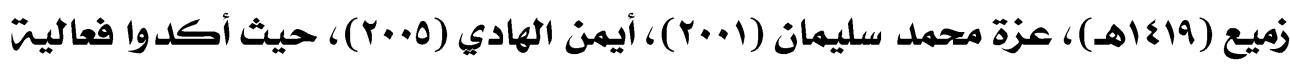

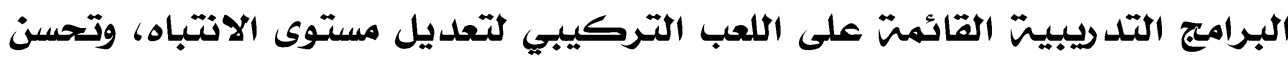

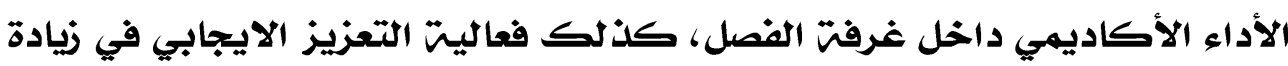

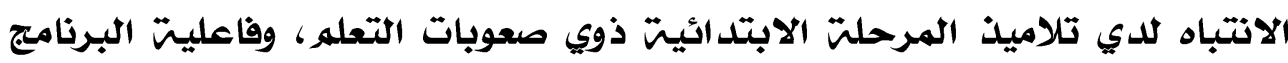

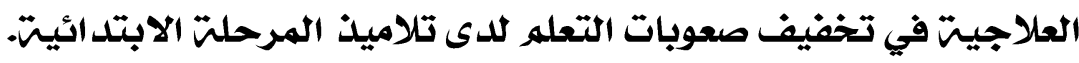

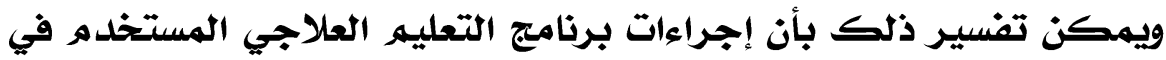

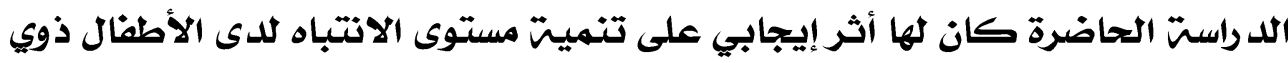

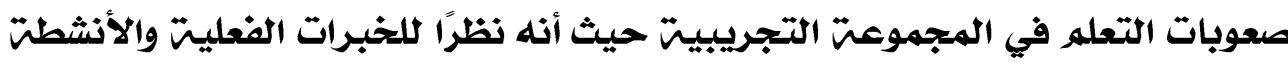

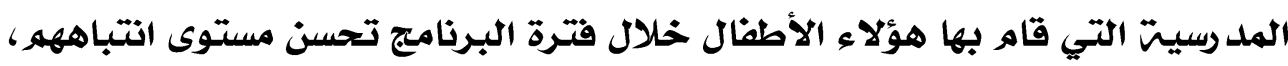

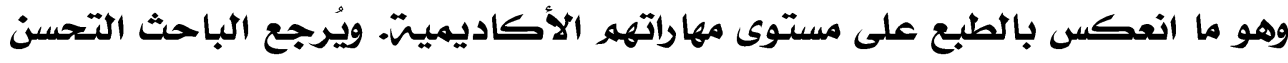

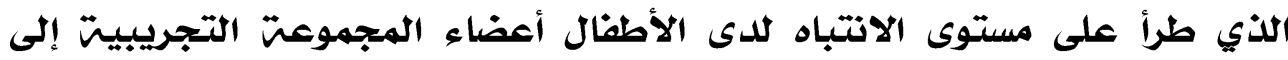

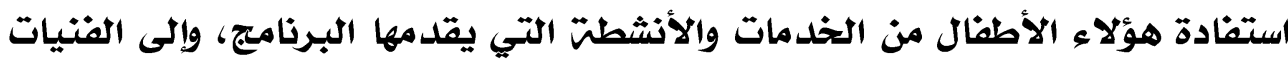

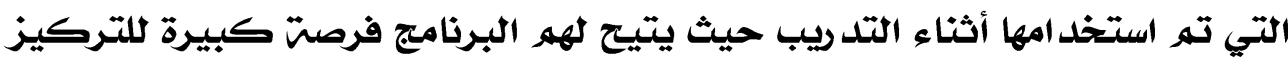

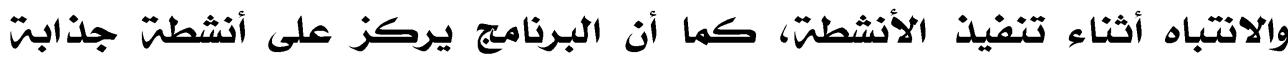

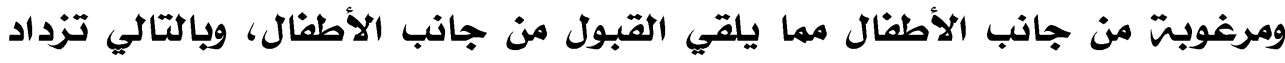

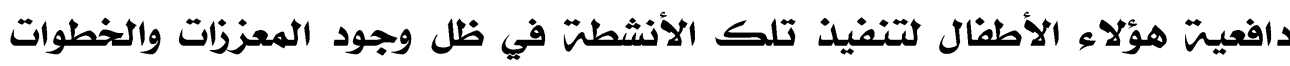

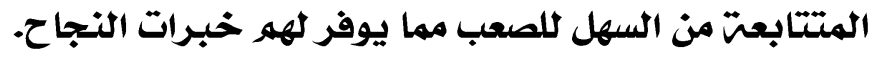




\section{(المراجع}

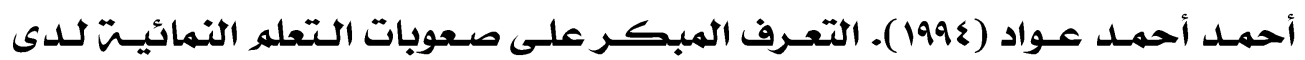

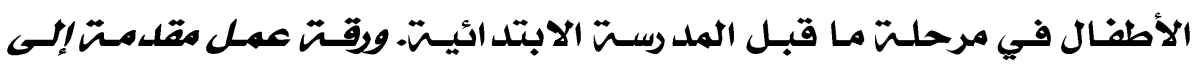

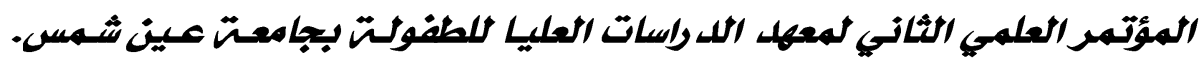

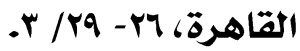

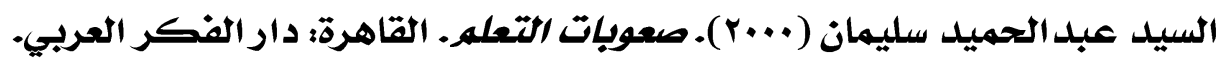

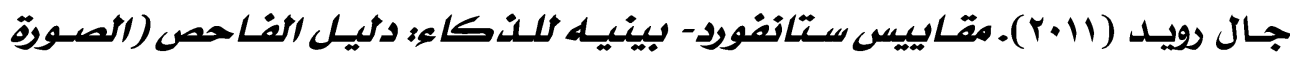

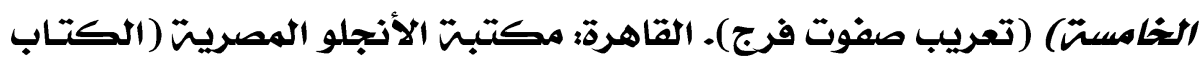

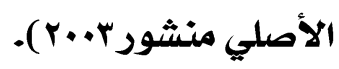

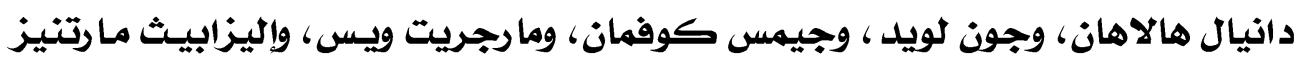

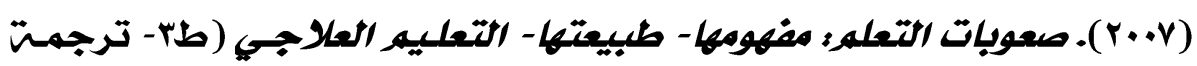

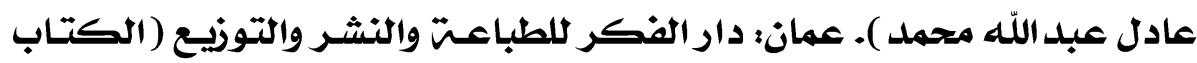

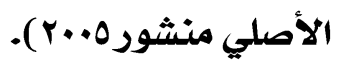

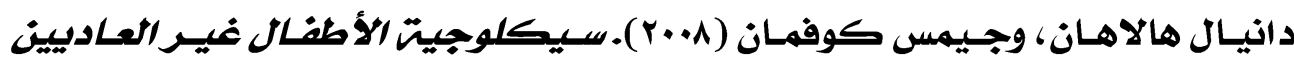

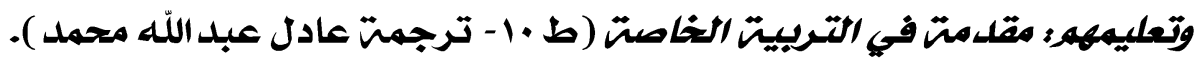

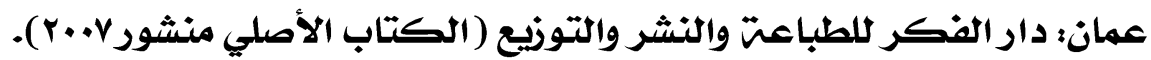

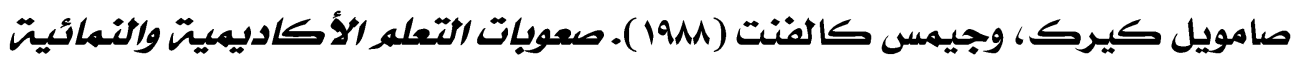

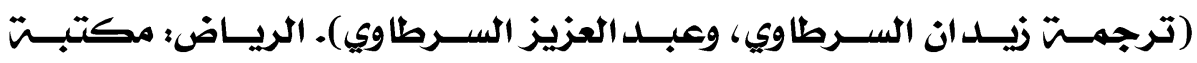

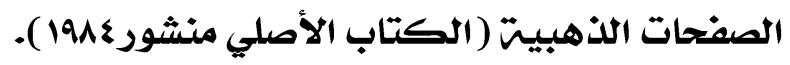

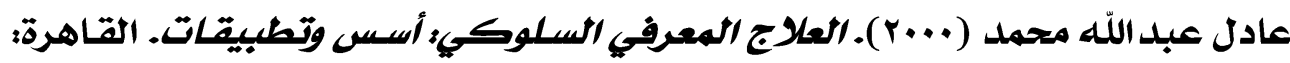

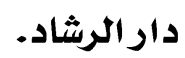

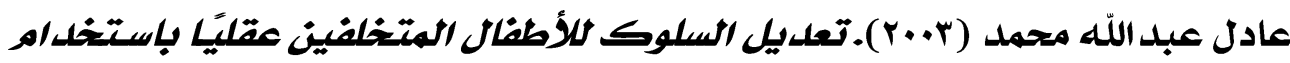
جلداول النشاط المصورة. القاهرة: دار الرشاد.

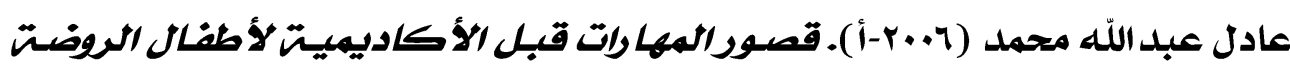
وصعوبات التعله. القاهرة: دار الرشاد.

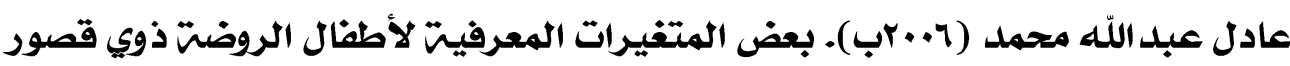

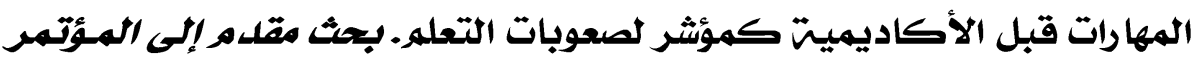

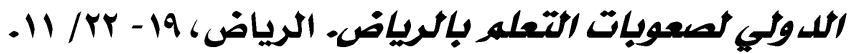

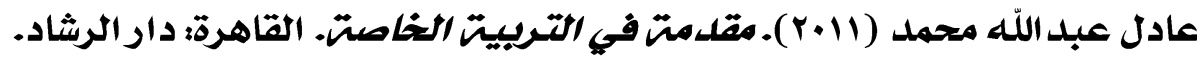

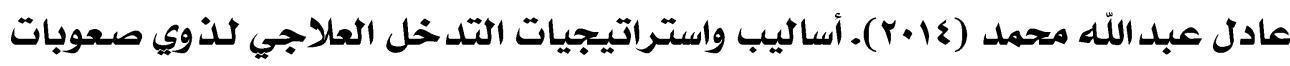

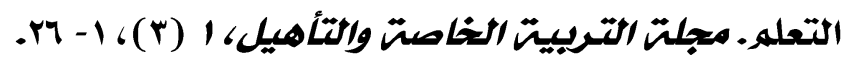




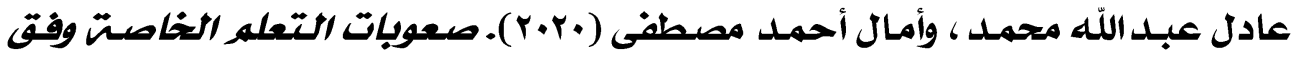

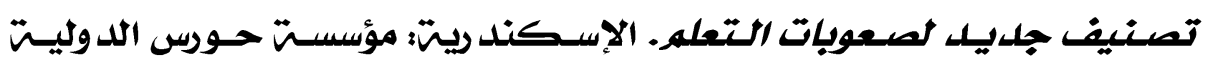
للطباعت والنشر والتوزيع. تولئ.

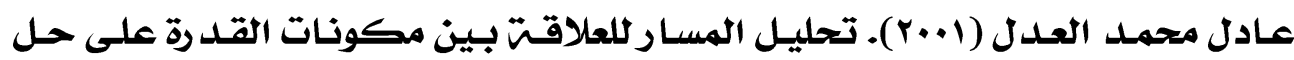
المشكات الاجتماعيت وكل من فعاليت الذات والاتجاه نحو المخاطرة. مجلت

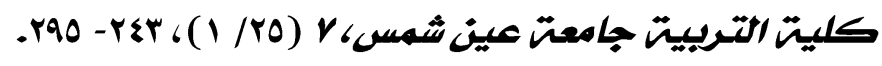

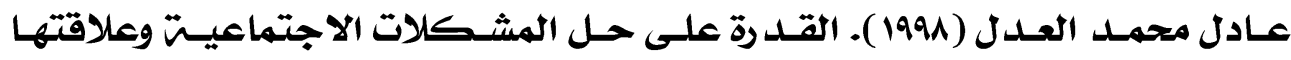

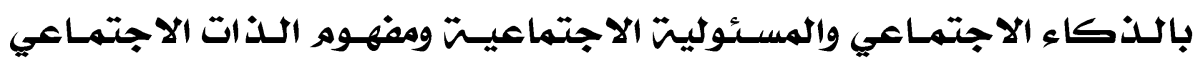

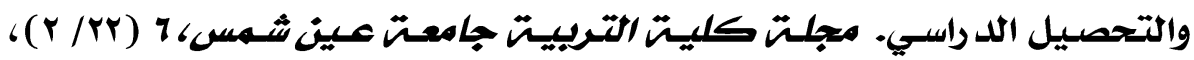
\&

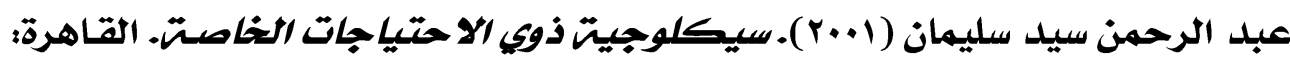
مكتبت زهراء الشرق.

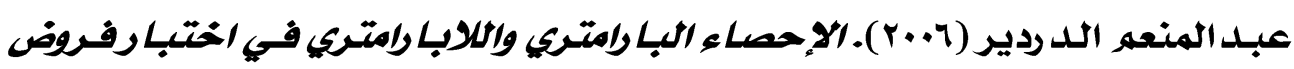

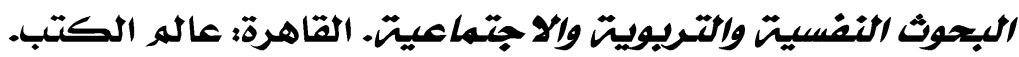

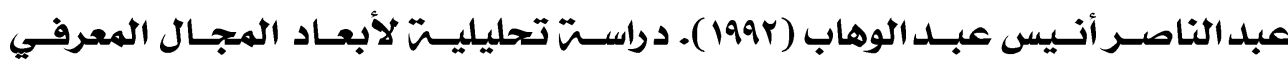

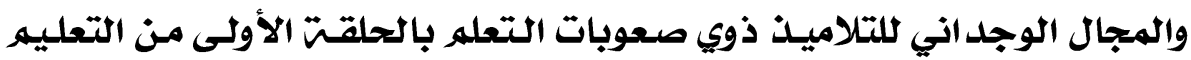

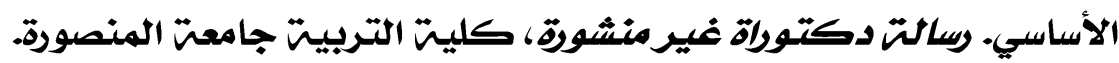

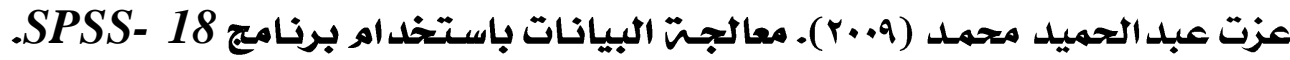
القاهرة: دار الفكر العربيل مجدي.

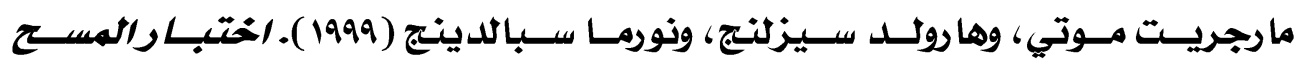

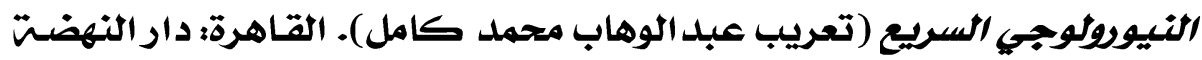

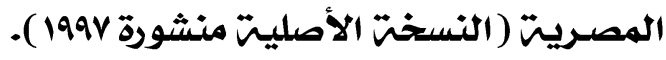

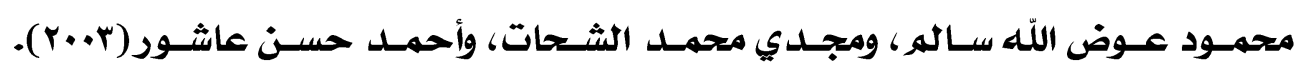

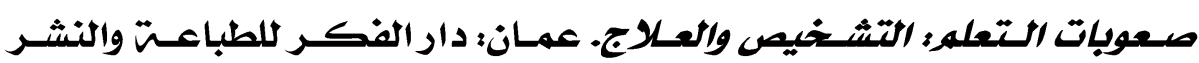
والتوزيع.

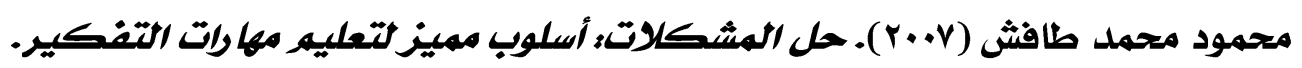
عمان: داروائل للنشر.

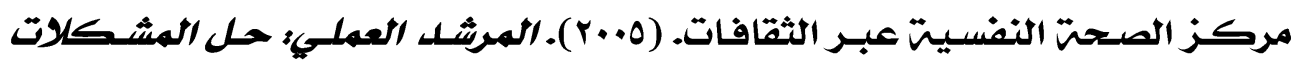

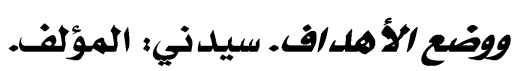

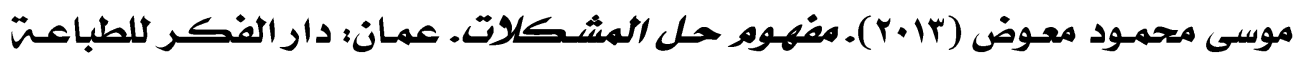
والنشر والتوزيع. 
American Psychiatric Association APA. (2013). Diagnostic and statistical manual of mental disorders, DSM-V. Washington, DC: Author.

Ames, C. (1981). Competitive versus cooperative reward structures: The influence of individual and group performance factors on achievement attributions and affect. American Educational Research Journal, 18 (3), 273-287.

Aronson, E., \& Patnoe, S. (2011). Cooperation in the classroom: The jigsaw method. New York: Printer\& Martin Limited.

Brownell, C., Zerwas, S.,\& Balaraman, G. (2002). Peers, cooperative play, and the development of empathy in children. Behavioral and Brain Sciences, 25, 28- 30.

Cecchini, M. (2018). Encouraging cooperative play. Baltimore: Excellience Learning Corporation.

Dewar, G. (2014). How to help your child develop social skills through cooperative play. Tiburon, CA: H. J. Kramer.

Fax, J.,\& Murray, R. (2004). Information flow and cooperative control of vehicle formations. IEEE Transactions on Automatic Control, 49 (9), 1465-1476.

Field, A. (2015). Preschool is a time to start encouraging cooperative play. Chicago: University of Chicago Press.

Fletcher, J., Lyon, G., Barnes, M., Stuebing, K., Francis, D., Olson, R.,\& Shywitz, B. (2001). Classification of learning disabilities: An evidence- based evaluation. Paper presented at the LD Summit. Washington, DC: U.S. Department of Education.

Frankel, F., Myatt, R., Cantwell, D.,\& Feinberg, D. (1997). Parent- assisted transfer of children`s social skills training. Journal of the American Academy of Children and Adolescent Psychiatry, 36 (1), 1056- 1064.

Garaigordobil, M., Maganto, C.,\& Etxeberría, J. (1996). Effects of a cooperative game program on socio-affective relations and group cooperation capacity. European Journal of Psychological Assessment, 12 (2), 141-152.

Garvey, C. (1990). Play: The developing child series. Cambridge, Massachusetts: Harvard University Press.

Gol, D.,\& Jarus, T. (2005). Effect of a social skills training group on every day activities in LD children. Journal of 
Developmental Medicine and Child Neurology, 23 (3), 456463.

Greenham, S. (1999). Learning disabilities and psychosocial adjustment: A critical review. Child Neuropsychology, 5, 171-196.

Hallahan, D.,\& Kauffman, J. (2007). Exceptional learners: Introduction to special education $\left(10^{\text {th }}\right.$ ed.). New York: Allyn\& Bacon.

Hallahan, D., Lloyd, J., Kauffman, J., Martinez. E.,\& Weiss, M. (2005). Learning disabilities: Foundations, characteristics, effective teaching ( $3^{\text {rd }}$ ed.). Boston: Allyn\& Bacon.

Hayes, J. (1989). The complete problem solver. New Jersey: Hillsdale, Lawrence Erlbaum Associates Publishers.

Heidemann S.,\& Hewitt, D. (1992). Pathways to play: Developing play skills in young children. St. Paul, MN: Redleaf.

Herrmann, K. (2013). The impact of cooperative learning on student engagement: Results from an intervention. Active Learning in Higher Education, 14 (3), 175-187.

Hirsch, B. (2016). Cooperative group play social skills training for children with social, emotional, and behavior challenges: Impact on self-esteem and social skills. Unpublished Ph. D. dissertation, Philadelphia College of Osteopathic Medicine PCOM.

Hudson, P. (1997). Using teacher- guided practice to help students with learning disabilities acquire and retain social studies content. Learning Disability Quarterly, 20, 23- 31.

Hughes, F. (2009). Children, play, and development. London: SAGE.

Jahr, E., Eldevik, S.,\& Eikeseth, S. (2000). Teaching children with autism to initiate and sustain cooperative play. Research in Developmental Disabilities, 21 (2), 151- 169.

Kameenui, E. (1996). Shakespeare and beginning reading: The readiness is all. Teaching Exceptional Children, 27 (2), 321.

Kavale, K. (2001). Discrepancy models in the identification of learning disability. Paper presented at the LD Summit. Washington, DC.; U.S. Department of Education. 